\title{
ÆUSGS

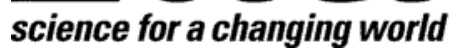

Digital Method for Regional Mapping of Surficial Basin Deposits in Arid Regions, Example from Central Death Valley, Inyo County, California

By A.S. Jayko ${ }^{1}$, C.M. Menges ${ }^{2}$, and R.A. Thompson ${ }^{3}$

2005

Open-File Report 2005-1445

${ }^{1}$ U.S. Geological Survey, 3000 East Line Street, Bishop, CA, 93514; to whom all enquiries should be directed

${ }^{2}$ U.S. Geological Survey, Tuscon, Ariz.

${ }^{3}$ U.S. Geological Survey, Denver, Colo.

U.S. DEPARTMENT OF THE INTERIOR

Gale Norton, Secretary

U.S. GEOLOGICAL SURVEY

P. Patrick Leahy, Acting Director 


\title{
DIGITAL METHOD FOR REGIONAL MAPPING OF SURFICIAL BASIN DEPOSITS IN ARID REGIONS, EXAMPLE FROM CENTRAL DEATH VALLEY, CALIFORNIA
}

\author{
Jayko, A.S. ${ }^{1}$, Menges C.M. ${ }^{2}$, and Thompson R.A. ${ }^{3}$ \\ U.S. Geological Survey \\ ${ }^{1}$ Bishop, Calif., ${ }^{2}$ Tucson, Ariz., and ${ }^{3}$ Denver, Colo.
}

\begin{abstract}
Derivative maps generated from DEM's and panchromatic remote sensing data (TM Landsat 7 or SPOT) can be used to characterize surficial basin deposits in arid regions dominated by basin and range topography. Results indicate the technique is useful for rapid digital mapping of surficial deposits where a first order, systematic subdivision of bedrock, alluvial fan units, and playas is unavailable at regional scales. Digital mapping can provide information about relative age and material properties of units that in part can be derived from the position of units within the basin. This automated mapping, implemented in a GIS system, involves an iterative process applied to a combination of digital elevation models (DEM) and satellite image data, such as SPOT or the highresolution panchromatic Band 8 of Landsat 7 scenes.

The method first discriminates the region into first-order terrains consisting of bedrock mountain highlands, basin piedmonts, and playa-basin interiors based on user-defined slope cutoffs applied to DEM data. The basin areas are subsequently classified into surficial map units such as active channels, ground-water discharge zones, and multiple age alluvial-fan piedmont units based on reflective properties of the associated surfaces in the satellite imagery. The surficial units are differentiated through systematic classification based on specific user-defined ranges of spectral values for each unit. The spectral ranges used in the classification are largely dependent on the composite effects of surface characteristics and material properties, including depositional morphology and texture, pavement development, degree of surface clast varnishing, and (or) properties of exposed soils of the alluvial fan units. We have used the slope-curvature properties derived from the DEM data to discriminate the bajada areas that exhibit non-unique spectral characteristics. Slope curvature is particularly effective at differentiating young undissected surfaces from older dissected piedmont units.
\end{abstract}


Available geologic maps and field observations may be used both to iteratively calibrate the spectral classification scheme and to provide additional verification of the digital map output. Digital mapping combined with detailed field studies in selected areas provides useful regional maps of surficial units until time and funding is available for more field intensive studies. In addition, anomalous areas on the thematic maps indicate where more detailed field or air photo work is warranted. The technique successfully distinguishes between bedrock, alluvial fans (generally multiple fan units), active washes, playas, playa rimming marshes and seeps and other active and inactive discharge zones in arid basin and mountain regions. Limitations occur in the subdivision of some fan units where the dominant detrital clast lithologies are not susceptible to varnish development.

\section{Introduction}

There is an important need for providing regional scale maps that show the distribution of surficial units in alluvial basins from arid regions, especially at 1:1,000,000 to 1:250,000 scales, but extending usefully to 1:100,000 scale. Until systematic field and air photo mapping can be completed, interpretation of remote sensing and digital terrain data can provide a preliminary framework for discriminating surficial units. The ability to digitally characterize basin deposits and geomorphic features has broad applications to planning as well as modeling of groundwater, ecological and climate change impacts.

Death Valley has often been used for pilot studies to demonstrate the capability of remote sensing techniques to differentiate Quaternary as well as bedrock map units (Fox et al 1990, Gillespie, 1999; Gillespie et al, 1984; Kruse, F.A. et al, 1993) which makes it a useful region to further explore application of digital mapping techniques. The antiquity of the alluvial fan deposits has been digitally estimated from the maturity or degradation of desert pavement that forms on the fan surfaces (c.f. Gillespie et al, 1984; Farr and Gillespie, 1984).

Previous work combining remote sensing with digital terrain elevation data to map surficial units has focused on mapping alluvial fans and determining relative tectonic activity along active range fronts (Farr and Chadwick, 1996) and to local examination of alluvial fans (Thiessen and Farr, 1996) which resulted in a subdivision of fan units into young, intermediate and old based on reflectance characteristics. Miliaresis and Argialas (2000) used a 2 to 7 degree slope range from the USGS $90 \mathrm{~m}$ DEM to extract the area underlain by the head and intermediate part of alluvial fans 
along the east side of Death Valley adjacent to the Black Mountain Range front; and used TM Band 1 data to capture the toe, or distal part of the fan these discreet conical fans. Miliaresis (2001) also used a block majority filtering of the drainage network in the 2-11 degrees slope range to select for the non-bedrock area underlain by fan or pediment.

In addition, remote sensing has been used to differentiate and identify evaporite deposits on playa surfaces (Crowley, 1993; Crowley and Hook, 1996; Stearns et al, 1999). Detailed field mapping of the salt deposits in Death Valley by Hunt and Mabey (1966) was based on a scheme of systematic sampling and field traverses in addition to standard air photo interpretation. Thus, they are able to show salt units that cannot be differentiated on the monochromatic imagery, but that can be mapped by using the increased spectral content of the TM data as demonstrated by Crowley and Hook (1996).

Remote sensing images of desert regions show stunning detail of bedrock and basin features (Figure 1), but study of the images has not, to date, resulted in systematic regional mapping or classification schemes that are actively used to derive surficial deposits maps from the image data. This study builds on previous work by digitally subdividing the entire arid basin system into alluvial units and subdivides the fan complexes into the alluvial $\left(\mathrm{Q}_{1-4}\right)$ system established by Bull (1991)

There are few currently available geologic maps of the Quaternary basins or valley floors that show subdivisions of the non-bedrock units for large regions. The objective of the effort described in this paper was to develop a digital method to produce regionally consistent surficial basindeposit maps that differentiate surfaces underlain by playa, marsh and seepage areas, stream channels, alluvial fans, and where possible, to subdivide the fan units based on the intensity of varnish development, surface smoothness, and degree of dissection (Gillespie et al, 1984; Farr and Gillespie, 1984; Jayko and Pritchett, 1999; Jayko and Menges, 2001). The approach was to develop systematic steps to generate the map from a combination of digital elevation data (DEMs), satellite imagery using a GIS platform and digital processing techniques to discriminate surficial basin units. The product is a map similar to one produced over a much longer time period by conventional mapping techniques using air photo interpretation. The method has been developed and tested in a portion of Death Valley containing suitable landscape and deposits that have been independently mapped by methods that permits testing verification of results. However, the method can be applied to other desert regions with low vegetation and similar landscape properties. 


\section{Surficial basin units}

Early work in delineating the surficial deposits in the Death Valley area of Figure 1 was undertaken by Hunt and Mabey (1966), who mapped the central Death Valley basin and adjacent bedrock at 1:96,000 and by Denny (1965), who mapped several alluvial fan complexes in this basin as well as areas to the east. Wright and Troxel (1993) and Slate and Berry (1999) added a complete suite of surficial deposits to bedrock mapping in north-central Death Valley at intermediate to regional scales of 1:48:000 to 1:100,000. General geomorphic and stratigraphic descriptions of Quaternary and basin units, with localized detailed mapping, have been completed in various parts of Death Valley generally as part of topical studies of neotectonic deformation or paleolake stratigraphy (e.g., Hooke ,1972; Brogan et al., 1991; Klinger and Piety, 2000; Knott, 1998; Machette et al., 2001). All of these studies used conventional mapping techniques applied to conventional aerial photography. A smaller number of maps with surficial mapping exists in basins to the east of central Death Valley (Denny and Drewes, 1965; McKittrick, 1988). More recently Menges et al (2001) and Workman et al (2002) produced a regional geologic map at 1:250,000scale of the entire Death Valley region and areas to the north and east, including the entire region of Figure 1, that includes a complete suite of surficial deposits (Table 1). These surficial units were identified and mapped on specially processed Landsat $5 \mathrm{TM}$ images in conjunction with standard aerial photography and selected field transects.

Many surficial basin units have primary geomorphic and geochemical characteristics that form in response to processes associated with aggradation, degradation, exposure and groundwater discharge. These characteristics can be recognized from digital analysis of their morphology, as represented in DEMs, and (or) by their spectral properties recorded in remotely sensed data such as satellite imagery (SPOT or Landsat TM). Through digital analysis, we can readily discriminate actively modifying basin landscape with features including alluvial fans, dunes, ground water discharge, and playas, as well as paleo features such as incised alluvial surface, shorelines, paleochannels, and paleo-groundwater discharge areas. The surficial basin units can be broadly grouped based on their relatively distinct geomorphic expression, without requiring additional analysis of their spectral characteristics (Table 1). 
We follow common practice in developing the stratigraphic nomenclature of surficial basin deposits that is portrayed in the digital maps and summarized in Table 1. In particular, we reference two studies, Hunt and Mabey, (1966) and Workman et al (2002), that produced maps of surficial deposits in the Death Valley-Amargosa region (Figure 1) at differing scales and level of detail. Both studies emphasized a time-dependent sequence of alluvial deposits that are commonly associated with alluvial fans on flanking piedmont slopes of basins, but that also can be identified along major axial channel systems in the interior of basins. The relative ages of the sequences can be identified in the field and interpreted on aerial photography or satellite imagery by a number of age-dependent features based in part on surface morphology, degree of varnish on surface clasts, degree of soil development, presence of clay, and relative degree of internal dissection (Table 1). The alluvial sequences from both studies cited above can be correlated with a regional chronosequence of climate-controlled deposits described by Bull (1991) in the lower Colorado region, and thus we use his nomenclature $\left(\mathrm{Q}_{1}\right.$ to $\left.\mathrm{Q}_{4}\right)$ in subsequent discussion.

The map stratigraphy from both studies also included a number of non-alluvial deposits not specifically addressed in the sequence of Bull (1991) (Table 1). For example, Hunt and Mabey (1966) described a detailed subdivision of fine-grained basin-interior sediments that particularly focused on various facies of salt-pan deposits widely exposed on the floor of central Death Valley, but also included some fine-grained alluvium, eolian deposits, and local lacustrine deposits associated with ancestral Pleistocene lakes. The stratigraphy of Workman et al (2002) and Menges et al (2001) depicts a more diverse set of deposits across a wide range of basins with varying source terrains and geomorphic characteristics. This stratigraphy includes not only fine-grained basinfloor alluvium, salt-pans, eolian deposits, and lacustrine deposits, but also includes fine-grained, commonly light-toned, sediments associated with non-salt playas and active and inactive groundwater discharge zones (e.g., the Ash Meadows area of the Amargosa Desert). Both studies also contain units representing locally extensive, commonly highly dissected, zones of basin-fill deposits ranging from late Tertiary to Quaternary age. These variably cemented and locally deformed sediments record basin deposition predating the younger set of surficial deposits in the basins that are morphologically associated with recognizable geomorphic elements within the present basin floor (e.g., alluvial fans, channels, basin floors and playas, or spring-paleospring discharge zones). 


\section{Characteristics of surficial basin units}

The alluvial fan units digitally mapped in this study approximately correlate with units defined and mapped by Hunt and Mabey (1966) for Death Valley (Table 1 and 2). Most workers, including Hunt and Mabey (1966), have divided alluvial fan deposits into at least 4 to 5 units. Herein we follow the nomenclature $\left(\mathrm{Q}_{1-4}\right.$ designations) established by Bull (1991) to identify the fan units in the American southwest deserts. The panchromatic TM Landsat 7 Band 8 and SPOT imagery can be used to discriminate at least three fan units based on the relative amounts of varnish and clay which tend to vary inversely with time. The intensity of varnish development is commonly associated with increasing maturity of smooth desert pavement on fan deposits and can be used to estimate relative age (Gillespie et al, 1984; Farr and Gillespie, 1984). The surface distribution of clay and silt are useful in discriminating various playa and active stream channel deposits. The varnish is expressed as areas of low reflectance, whereas the clay content is expressed as high reflectance in the panchromatic imagery.

The surface weathering characteristics of these units that enables the digital differentiation from spectral characteristics as follows: the active or 'Holocene' wash $\left(\mathrm{Q}_{4}\right)$; a late Holocene deposit with no pavement and at most weak varnish $\left(\mathrm{Q}_{3} \mathrm{c}\right)$; two intermediate deposits defined primarily by the absence or incipient degree of pavement development, also partly expressed by the rock-varnish development $\left(\mathrm{Q}_{3} \mathrm{a} \& \mathrm{Q}_{3} \mathrm{~b}\right)$; well developed smooth pavement and strongly varnished surfaces $\left(\mathrm{Q}_{2}\right)$; and dissected, weakly to moderately varnished deposits commonly littered on the surface with secondary, light colored chips of secondary pedogenic carbonate $\left(\mathrm{Q}_{1}\right)$. The middle and late Quaternary alluvial fan deposits $\left(\mathrm{Q}_{2}\right.$ and $\left.\mathrm{Q}_{3}\right)$ can be differentiated based primarily on reflectance, which is generally controlled by varnish development. The late Quaternary active wash $\mathrm{Q}_{4}$ unit can be distinguished primarily based on the high clay content and little or no varnish.

Accurate differentiation into the various age-related categories can be complicated by the sensitivity of varnish development to the dominant lithology of surface rock clasts. Certain rock types preferentially develop strong varnish (for example, mafic or intermediate volcanic rocks, metamorphic rocks and quartz-rich sedimentary rocks) relative to other lithologies such as carbonate and granitic rock that inhibit varnish development, thus creates problems in 
differentiating $\mathrm{Q}_{2-4}$ units by reflectance alone as noted earlier. However, this was not a significant problem in the Death Valley and Amargosa area and can be addressed by calibration with existing geologic maps or field data.

Active marsh and seep deposits forming wet vegetated areas that have very low reflectivity occur in central Death Valley where the distal fan deposits reach the playa or mudflats in the basin interior. The discharge areas at the fan margins generally have higher carbonate and fine sand relative to the salt and silt that dominates the greater playa surfaces (Hunt and Mabey, 1966). This interface between the distal fan and playa deposits coincides with a subtle slope break. Thus, seep and marsh deposits typically occur where extremely low reflectance coincides with extremely low slopes. Marsh and seep areas can be classified as low reflectance areas on that part of the imagery selected from the 0-1 degree DEM slope domain. In contrast, the playas and mudflats have high reflectance and low slopes. In steeper areas, discharge zones cannot be easily distinguished because the reflectance values on monochromatic imagery overlap with the reflectance of heavily varnished surfaces on the older alluvial fan pavements, although discharge zones area rare in the more steeply sloping part of the study area. Although not used in this study, other TM spectral bands can be used if its necessary to isolate the vegetated areas associated with active discharge. To the east of Death Valley in the Amargosa area, low-reflectance areas of dense vegetation coincide with local zones of active spring discharge and ground-water seepage in areas such as Ash Meadows. Most of the Ash Meadows area, however, is underlain by light-toned, highly reflective paleodischarge deposits, consisting mostly of sparsely vegetated to barren areas of fine-grained sand and silt that correspond to currently inactive zones of past ground-water discharge during the wet intervals of the Pleistocene (Quade and others, 1995). Thus, the geomorphic context and understanding of desert geomorphic environments is important in interpretation of the results.

\section{Methods}

We use a GIS system to map surficial units by processing and combining elevation and satellite image data (Figure 2). We used U.S.G.S. 30 m Digital Elevation Models (DEM's) and Landsat7 $15 \mathrm{~m}$ TM imagery (panchromatic Band 8) acquired Oct., $15^{\text {th }}, 1999$, scene ID LE7040035009928850. Although SPOT 15 panchromatic data was tested successfully (Jayko and Pritchett, 1999; Jayko and Menges, 2001) it requires edge matching of scenes for large study areas. The panchromatic Band 8 of TM imagery was selected because it provides $15 \mathrm{~m}$ resolution and, 
similar to aerial photography, is sensitive to all or most of the visible spectrum. The processing was done with ARC/INFO GIS software, although any GIS software with raster and vector formats could be used.

DEM derivatives (slope and curvature, which is a measure of the change of slope) were used to subdivide the large scale geomorphic features of the region. The slope grid was used to subdivide the terrain into three domains: bedrock, alluvial fans or pediments, and playas (Figure 3 and 4). The bedrock highland areas surrounding the basins were excluded from subsequent processing. The curvature grids were used to isolate the oldest $\left(\mathrm{Q}_{1}\right)$ from all the younger fan units $\left(\mathrm{Q}_{2-4}\right)$, and to improve the boundary between the steep-sloping bedrock domain and the adjacent basin domain. The quality of the available DEM's, which is variable for the study area, influences the quality of the derivative map.

Spectral ranges were used to subdivide the basin units (see below; Figure 5a and b). Spectral ranges corresponding to each surficial unit (Figure 4; Table 2) were obtained by quantitative analysis of basin units mapped by Hunt and Mabey (1966) in central Death Valley, and by Workman et al (2002) across the entire area of Figure 1. Further constraints on the spectral ranges of surficial units were provided by values obtained from field point observations. Each of these steps in the digital mapping process are described in more detail.

The sequence of processing was: 1.) subdivide area into slope domains to distinguish bedrock, pediment or alluvial fan, and playa areas; 2) subdivide the pediments and fan defined slope areas into $\mathrm{Q}_{2-4}$ and eolian units using spectral data classification; 3.) subdivide the playa defined slope area into playa, marginal seep and marsh, and active wash using spectral data classification (supervised); 4.) delineate $\mathrm{Q}_{1}$ and/or QTs using profile and plan curvature in conjunction with a slope delimited area; augment the bedrock area with curvature 5.) merge results into single grid; and 6.) evaluate results. Details of processing, method for selecting spectral ranges and characteristics of the units that lend themselves to digital manipulation are provided below. Units that are discriminated based on their morphological character alone include bedrock, older alluvial fan surfaces, and playas. Units that require a combination of terrain and spectral discrimination include dunes, active discharge areas and paleoground water discharge. Units that can be mapped from spectral data, after isolating bedrock from basin domains, includes active washes and subdivisions within alluvial fan complexes (i.e., $\mathrm{Q}_{2}, \mathrm{Q}_{3}, \mathrm{Q}_{4}$ ). 


\section{Slope domains}

Digital terrain data (30 m DEM's) are used to delineate the basic first-order topographic domains with similar slope characteristics. The slope domains are obtained by classifying the slope map into three areas, 0-1.0, 1.1-16, and >16 degrees (Figure 3 and Table 3). These domains generally discriminate the areas underlain by playa, alluvial fan deposits and bedrock surfaces, respectively, although the cutoff values can be adjusted empirically to best fit the given area.

The slope ranges for the bedrock cutoff were selected by histogram cutoffs (Figure 3) and querying the slope grid using a rasterized version of Hunt and Mabey (1966). There is some overlap between bedrock and alluvial fan deposits in the slope range from 7-16 degrees in the Amargosa area, especially where Neogene deposits are gently folded or faulted. However, for the purposes of surficial deposits mapping it is most important to include all the area of surficial deposits, even if some areas of gently sloping bedrock are also captured. Most regions have 1:250,000 scale maps of the bedrock geology, so a bedrock boundary can be digitized if greater accuracy of that boundary is required.

Alluvial fans are characterized by low slopes ranging from negligible to 20 degrees, but generally do not exceed 10 degrees and typically range between 3 to 6 degrees (Bull, 1977). The areas underlain by $\mathrm{Q}_{2}-\mathrm{Q}_{4}$ units are mainly represented by the area with 1-7 degrees slope range using 30 m DEM's, whereas $\mathrm{Q}_{1}$ and QTs also include slopes ranging between 7 to 16 degrees (Figure 3 and Table 3). The 16 degree cutoff effectively includes about $~ 98-99 \%$ of the alluvial deposits in the study area. However, a smaller, 10 degree cutoff is even better suited for the Amargosa area to the east of Death Valley, which is more tectonically stable, thus contains more eroded highlands with more extensive development of pediment surfaces. A smaller slope cutoff of around 0.25 to 0.5 degrees would better delineate the distal fan and playa units in the Amargosa region, however the presently available $30 \mathrm{~m}$ DEM's do not have not sufficient resolution to map slopes within this range.

The playa slope domain is the most sensitive to the quality of the DEM which affects the sharpness of the boundary edge and the abundance of spurious data (Figure 4). The slope domains can be cleaned by 1.) generating a grid of the desired slope range and setting the rest of the area to nodata or a null value; 2.) setting the resultant slope grid to a constant value and then filtering the grid to fill in gaps and edges with the majority value within a user specified small search area (i.e. $2-3 x$ the grid spacing). Although the quality of available 30m DEM's is presently variable, and 
locally poor, we found this processing to be extremely useful, and will only be enhanced as DEM quality improves in the future. The poor DEM quality was most noticeable in the broad distal fan areas adjacent to the playas, where DEM irregularities in the 0-1 degree range impact smooth delineation of the playa boundary.

\section{Imagery classification}

We next classify the remote sensing data into the alluvial fan and playa units. The fan and playa areas that were isolated by slope analysis are each classified separately to generate the subdivisions of the $\mathrm{Q}_{2}$ to $\mathrm{Q}_{4}$, active wash and playa units. The classification process takes the raw image data, which has a possible range of 255 values, and categorizes them into a few meaningful groups of values (for example 6-8 groups) by applying user defined ranges. The classification of the spectral data can be simply dividing the features based on spectral data alone (unsupervised classification) or applying prior knowledge to help define features (supervised classification). There are several different ways to achieve a best-fit classification of the spectral ranges to represent the surficial map units, the options depend on the availability of pre-existing mapping and field observations.

We looked at three methods (1.) using natural steps or discontinuities in the spectral data that occur within the alluvial fan and playa slope domains (unsupervised) (2.) applying spectral means and majority ranges obtained by querying existing maps that were digitized for the exercise (supervised), and (3.) using spectral ranges obtained by querying the imagery with field locations with ground observations (supervised). And, used a combination of method 2 and 3 for the classification based on empirical comparison of the result to published geologic mapping.

For the Death Valley area, we digitized the Hunt and Mabey (1966) geologic map and rasterized it to use the unit zone grid to query for spectral ranges from the imagery (Figures 5a and b). We also had a vector copy of the surficial mapping from the Death Valley Regional Flow Model (Workman et al, 2002) covering the entire study area, as well as field observations of units with GPS-determined locations. Figure 5a and 5b show histograms of the spectral values found in the fan and playa units defined by Hunt and Mabey (1966), and Table 4 shows the statistics for values for alluvial and playa units. The cutoff and ranges, were refined empirically from the mean and majority values and cutoffs were refined with the ground truth data (Table 5, supervised classification) and the Death Valley Regional Flow Model (Table 6, supervised classification). The TM data for the fan and playa domains were then classified (Table 7) and the resulting thematic 
surficial deposits map was compared with unit boundaries from published geologic maps (Figure $6)$.

If a high degree of certainty is needed and the reliability of the published maps is in question, then a test area can be mapped in detail (referred to as training sites) and used to help delineate the appropriate spectral ranges to use for classification. A classification scheme, once established by calibration in a given map area, can then be applied to digital mapping of other unmapped areas with similar topography and types of deposits. The resulting digital map may also be improved by adjusting the cutoff values to make better agreement with published geologic map (supervised classification).

If there are no existing field observations or available mapping for calibration, the classification ranges can be selected empirically from natural steps that can be observed by generating a histogram of the spectral data. This method will breakout mappable units that can be field checked for their prominent surface characteristics, and can be improved with additional ground truth information. If reliable mapping at an appropriate scale or level of detail is available for correlation, then the thresholds based on natural steps in the spectrum can be combined by trial and error to find a best fit to published map unit areas.

\section{Curvature: fan domain}

The older, late Pliocene and/or early-middle Quaternary alluvial units ( $\mathrm{Q}_{1}$ and/or QTs) cannot be readily differentiated from the younger $\left(\mathrm{Q}_{2-4}\right)$ surfaces with spectral data alone because of similar reflectance characteristics. The similarity occurs because internal dissection of the old fan commonly degrades previously-developed varnished pavements on the interfluves, and bioturbation and/or erosion typically exposes abundant chips of secondary carbonate from the underlying petrocalcic soils. The net effect is to develop light tones and higher reflectivity on the images that commonly overlap with the spectral ranges principally associated with younger less varnished but undissected deposits including $\mathrm{Q}_{3}$ or even $\mathrm{Q}_{4}$ units.

However, the older fan units $\left(\mathrm{Q}_{1}\right.$ and QTs) are generally characterized morphologically by strong dissection and bajada morphology that can be used to isolate them from the weakly or undissected younger surfaces using curvature (second derivative of the DEM = change of slope) to define the amount of internal dissection. The curvature can be calculated with respect either to a vertical (profile) or horizontal (plan) plane (Figure 7). The profile curvature is a tool that enhances 
escarpments by defining sharp breaks of slope at the margins of interfluves and gullies. The curvature is calculated over $60 \mathrm{~m}$ area with $30 \mathrm{~m}$ DEM's. In profile, curvature, which generally ranges from about 5 to -5 (units $=1 / 100 \mathrm{~m}$ ), is displayed with positive curvature (convex upward) and negative curvature (concave upward), and flat where the curvature is near 0 (Figure 7). Cutoff values greater than 0.45 and less than -0.45 in the fan areas defined by the 1-16 degree slope domains were used to select the $\left(\mathrm{Q}_{1}\right.$ and/or QTs) from the younger fan units. In plan, curvature with values of greater than 0.25 and less than -0.25 ( $~ 1$ standard deviation from the mean) in the fan areas defined by 1-16 degree slopes, further augments the margins of interfluves and gullies within the $\mathrm{Q}_{1}$ and QTs units. Grids defining the dissected older units were composited from the profile and plan curvature grids (Figure 7 and 8). Delineation of the $\mathrm{Q}_{1}$ and QTs units is mainly limited by the quality of the DEMs which tends to be poorer in lower slope areas, and will only improve as higher quality DEM's become available in the future.

The extreme plan and profile curvature values can also be used to improve the boundary and inclusion of data cells within the area underlain by the highlands bedrock domain that represents bedrock but was not isolated by high slope value. This is done by compositing the slope defined bedrock domain with the extreme plan and profile curvature areas that exclude the fan and playa area (Figure 8). Likewise, the highlands bedrock domain can be further improved by adding TM Band 8 data cells representing the data from the slope-defined fan domain (1-16 degrees) that lie in the low spectral values (ie $\sim 0$ to 40 ). In a similar fashion the area of $\mathrm{Q}_{2-4}$ fans can be further isolated by subtracting the grid representing composited bedrock plus $\mathrm{Q}_{1}$ and QTs defined by curvature.

\section{Results}

We generate thematic surficial deposit maps by combining classified imagery (panchromatic TM Landsat 7 or 15m SPOT, Jayko and Pritchett, (1999) with morphologically defined areas derived from 30m digital elevation models (DEM). These maps can be empirically compared with (a) published geologic maps where surficial deposits have been mapped from air photo interpretation and field studies, for example, Hunt and Mabey (1966) 1:96,000 scale (Jayko and Pritchett, 1999), and with (b) preliminary regional surficial-deposit maps that have been developed from more conventional interpretative mapping of Landsat 7 TM satellite imagery plotted at 
1:100,000 to 1:250,000 scales with reconnaissance field observations (Menges et al, 2001; Workman et al, 2002), or c.) other relevant data layers such as shaded relief maps.

Figures 9a-d show examples of the preliminary basin deposit maps for the Central Death Valley area generated from digital processing of DEM's and TM Landsat 7, BAND 8 data using classification ranges derived from spectral values characteristic of Quaternary units mapped by Hunt and Mabey (1966) and Workman et al (2002). GPS point localities where the identification of units was made in the field are shown on Figure 9a. Table 8 and Figure $5 a$ and $b$ shows the variation in the spectral values of units that are classified on the thematic surficial deposits map. Table 9 shows the terms used for the qualitative assessment of the resulting thematic map in the discussion below.

Classification ranges calibrated from Hunt and Mabey (1966) geologic map of Death Valley work very well for differentiating correlative deposits in the Amargosa desert to the east. The surficial mapping of Workman et al (2002), which includes this study area, was also used to refine the classification scheme for surficial units over the entire study area including Death Valley in order to test whether more broadly based calibration could produce a digital map that closely replicates original map contacts across the area. This refinement of the a classification scheme initially based on spectral ranges derived from the Hunt and Mabey (1966) unit boundaries alone, improved the correspondence between the digital map and the Workman et al (2002) map units as well as the areas lying east of Death Valley.

The digital mapping technique was most successful where source areas for adjoining fan complexes contain lithologies susceptible to varnish development such as intermediate and siliceous volcanics, most quartzitic units, and metamorphic rocks. The digital mapping also appears to be more successful in the more tectonically active area (Death Valley proper) where there is greater contrast in morphological relief within different parts of the basin system than in the more tectonically stable Amargosa area. In general, the technique performed excellently for distinguishing Holocene deposits, in particular, Qp, Qlc, $\mathrm{Q}_{4}$, and Qsc in all areas. The technique underperformed for $\mathrm{Q}_{2}$ units where watersheds are dominated by mafic volcanic rock, especially basalt, which develop varnish on dark-colored initial surfaces that commonly resemble strongly varnished older surfaces on deposits with lighter-colored clast lithologies.

Preliminary results indicate a satisfactory to very good correspondence between the digital map result and field data and published maps (Figure $9 a$ and $b$ ). There is generally satisfactory 
correspondence in most of the alluvial fan areas, especially $\mathrm{Q}_{4}, \mathrm{Q}_{3}$ and $\mathrm{Q}_{2}$ units. Discrimination of alluvial deposits, especially $\mathrm{Q}_{3}$ versus $\mathrm{Q}_{2}$, still presents problems in some parts of the digital map when compared with the conventional mapping. For example, $\mathrm{Q}_{2}$ is over represented relative to $\mathrm{Q}_{3}$ on piedmont fans primarily derived from the Wood Canyon Formation in the southeastern part of the map area (Figure 9c), which produces dark-toned detritus in monochromatic images even on parts of the fan with young $\mathrm{Q}_{3}$ deposits. In contrast, $\mathrm{Q}_{2}$ deposits are under represented relative to $\mathrm{Q}_{3}$ deposits on piedmont fans derived from the southwest flank of the southern Funeral Mountains (Figure 9c) and on the northwestern section of Greenwater Valley (Figure 9d). This unsatisfactory differentiation results from the predominance of clast lithologies that do not easily develop or preserve varnish, such as carbonate rocks in the Funeral Mountains piedmont and granitic and altered volcanic rocks in the Greenwater Valley.

The lack of varnish development on deposits of successively greater age causes a relatively high reflectance for both old and young $\left(\mathrm{Q}_{2}\right.$ and $\left.\mathrm{Q}_{3}\right)$ deposits that is locally enhanced by degradation of pavements and reworking of underlying petrocalcic soils in the more dissected $\mathrm{Q}_{2}$ units. The unit differentiation is improved somewhat by use of the DEM data to distinguish slope curvatures related to the greater internal dissection in $\mathrm{Q}_{2}$ deposits. Additional digital processing with curvature captures a large part of the $\mathrm{Q}_{1}$ (older dissected fans) but, at this stage of the work, under represents its distribution, and so some $\mathrm{Q}_{1}$ tends to be classified primarily with $\mathrm{Q}_{2}$ instead. However, although improved by DEM curvature analysis, there are still problems in the differentiation of $\mathrm{Q}_{1}$ in both areas related to (a) the depth and spacing of $\mathrm{Q}_{1}$ dissection relative to the 30-m DEM resolution, and (b) spurious data points in the DEM data, which produce noise in the digital mapping in these areas as well as many other parts of the map (Figs. 9a-c). Acquisition of higher resolution and better quality DEM data would improve the quality of digital mapping throughout the map, but particularly in areas with significant amounts of the older fan unit $\mathrm{Q}_{1}$ that relies extensively on DEM curvature magnitude for the differentiation.

The composite map on Figure 10 is a shaded relief and stream network map generated from the DEM. The lines delineate surficial basin unit boundaries derived in this study and were generated by vectorizing the raster version of the basin unit map and digitally overlaying the coverage on the DEM base. For example, active channel wash units selected spectrally from the remote sensing image can be cross-checked and verified not only by comparing them with published geologic maps but also evaluating them against other digital data such as hydrologic digital line graphs 
(DLG) base layers, stream channels generated from DEM's, overlays with low-angle shaded relief maps, or digital contour maps. There is excellent agreement between the bedrock range front boundary and the alluvial piedmont, many fan units, and the distal fan boundary.

\section{Conclusions}

Preliminary work suggests the technique presented here shows promise as a tool for rapid objective and consistent mapping of large regions, at a regional scales (ie 1:100,000 to 1:250,000). One of the challenges of analog mapping by conventional techniques is to consistently define boundaries around areas with similar aerial photo characteristics. Variations in conventional mapping can be induced by changing air photo scales, photo reproduction quality, interpretive biases in mapping unit boundaries among individuals, and subjective decisions that can drift during the mapping process, which may require months, if not years, of mapping effort.

The technique is best suited for mapping surficial deposits in basins in arid to semiarid desert largely devoid of vegetation (Figure 1). The method is particularly useful in the hyperarid to arid lower elevation areas where vegetation density is very low, the dominant scrub vegetation is sparse creosote, and varnished pavements are well developed on older surfaces with clast lithologies susceptible to varnish development. Alluvial unit discrimination was less successful where the basins lie above 4000 to 4500' such as the Greenwater basin east of central Death Valley where greater precipitation supports more closely spaced and robust vegetation, although many well developed $\mathrm{Q}_{2}$ type pavements could be consistently identified even in these areas.

Surficial units in the Death Valley basin are more distinctive and thus, are easier to digitally characterize, than those of the Amargosa basin and higher elevation basins such as in the Greenwater Valley. This is in part due to (1.) the high rate of tectonism that affects slope and incision properties, and (2.) higher temperatures and very low precipitation that results in extremely low vegetation and dominance of salts in both soils and on the basin floor in Death Valley. Thus, the digital tools can greatly assist delineating surficial units, but still require fundamental field based studies and understanding of the geomorphic context.

Digital surficial deposits maps generated from remote sensing and DEM data also provide significant detail in unit distributions in many areas (eg., complex intermixing of $\mathrm{Q}_{4}$ and $\mathrm{Q}_{3}$ deposits in areas of active and recent fan deposition) that, although easily generalized to accommodate map-scale requirements, may be of interest for more specialized or topical studies. 
The correspondence is especially good between various $\mathrm{Q}_{2}, \mathrm{Q}_{3}$, and $\mathrm{Q}_{4}$ alluvial deposits on many piedmont fans with parent lithologies sensitive to varnish development (eg., those in southwest and southeast sides of central Amargosa Desert basin (Figure 9c). The digital mapping also sharply discriminates active or very young channels from older surfaces along the complex axial channels system of the Amargosa River as well as areas of extensive exposures of paleodischarge deposits in Ash Meadows in northern and central parts of the Amargosa Desert (Figure 9c).

\section{Acknowledgements}

We thank Tom Bullard, Desert Research Institute; Jack Schmidt, University of Bonn; Van Williams, Sue Beard and Sarah Robinson, U.S.G.S., and Peter Guth, U.S.Naval.Academy for insightful and helpful reviews which have greatly improved early drafts of this paper paper.

\section{References}

Brogan, G.E., Kelloge, K.S., Slemmons, D.B., and Terhune, C.L., 1991, late Quaternary faulting along the Death Valley-Furnace creek system, California and Nevada: U.S. Geological Survey Bulletin 1991, 23p.

Bull, W.B., 1997, The alluvial fan environment: Progress in Physical Geography, v. 1, p. 222-270.

Bull, W.B., 1991, Geomorphic Responses to Climatic Change: Oxford University Press, New York, $326 \mathrm{pp}$.

Christenson, G.E. and Purcell, C., 1985, Correlation and age of Quaternary alluvial-fan sequences, Basin and Range province, southwestern United States: Geological Society of America Special Paper 203, p. 115-122.

Crowley, J.K, 1993, Mapping playa evaporite minerals with AVIRIS data; a first report from Death Valley, California: Remote Sensing of Environment, vol.44, no.2-3, p.337-356.

Crowley, J.K; Hook, S. J., 1996, Mapping playa evaporite minerals and associated sediments in Death Valley, California, multispectral thermal infrared images: Journal of Geophysical Research, B, Solid Earth and Planets, vol. 101, no. 1, p. 643-660.

Denny, C.S., 1965, Alluvial fans in the Death Valley region, California and Nevada: U.S. Geological Survey Professional Paper 466, 62 p.

Denny, C.S., and Drewes, H., 1965, Geology of the Ash Meadows Quadrangle, Nevada-California: U.S. Geological Survey Bulletin 1181-L, L1-L56, map scale 1:62,500. 
Farr, T. G., 1996, Use of digital topography and remote sensing to map tectonic activity of range fronts: Geological Society of America, Abstracts with Programs - v. 28, n. 7, p. 463.

Farr, T. G. and Chadwick, O.A., 1996, Geomorphic processes and remote sensing signatures of alluvial fans in the Kun Lun Mountains, China: Journal of Geophysical Research, v 101, p. 23091-23100.

Farr, T. G. and Gillespie, A.R., 1984, Measurement of micro-relief on alluvial fans and its relation to age, lithology, and radar response: Geological Society of America, Abstracts with Programs v. 16, p. 506.

Fox, L. III, Fischer, A.F., III, Gillespie, A.R., and Smith, M.O., 1990, Investigation of AVIRIS imagery for application in differentiating soil chronosequences: Proceedings of the Second Airborne Visible/Infrared Imaging Spectrometer (AVRIS) Workshop, Jet Propulsion Laboratory Publication 90-54, Pasadena, p. 94-99.

Gillespie, A. R., 1999, Thirty years of remote sensing in Death Valley-What have we learned?: in Slate, J. L. ed, Proceedings of Conference on Status of Geologic Research and Mapping in Death Valley National Park, Las Vegas, Nevada, April 9-11: U.S. Geological Survey OpenFile Report 99-153, p. 85-89.

Gillespie, A.R., Kahle, A.B., and Palluconi, F.D., 1984, Mapping alluvial fans in Death Valley, California using multichannel thermal infrared images: Geophysical Letters, v.11, p. 11531156.

Hooke, R. LeB. 1972, Geomorphic Evidence for Late-Wisconsin and Holocene Tectonic Deformation, Death Valley, California: Geological Society of America Bulletin, v. 83, p. 20732097.

Hooke, R.L., 1968, Processes on Arid-Region Alluvial Fans: Journal of Geology, v. 75, p. 438-460.

Hunt, C.B., and Mabey, D.R., 1966, Stratigraphy and Structure, Death Valley, California: U.S. Geological Survey Professional Paper 494-A, p. 1-162.

Jayko, A.S. and Menges, C.M., 2001, A short note on developing digital methods for regional mapping of surficial deposits in arid regions using remote-sensing and DEM data: in Machette, M.N., Johnson, M.L. and Slate, J.L., eds, Quaternary and Late Pliocene Geology of the Death Valley region: Recent observations on Tectonics, Stratigraphy and Lake Cycles: U.S. Geological Survey Open-File Report 01-51, p. 167-172.

Jayko, A.S. and Pritchett, D.W., 1999, Regional 1:100,000 mapping of Quaternary units from SPOT images and 30-m DEM's, in Slate, J., ed., Proceedings of Conference on Status of Geologic Research and Mapping in Death Valley National Park, Las Vegas, Nevada, April 911: U.S. Geological Survey Open-File Report, 99-153, p.106. 
Klinger, R.E., 2002, Quaternary stratigraphy, soil geomorphology, and tephrochronology of northern Death Valley fault zone: Univ. Colorado, Boulder, Ph.D. dissertation.

Klinger, R.E., and Piety, L.A., 2000, Late Quaternary tectonic activity on the Death Valley and Furnace Creek faults, Death Valley, California: Geologic and geophysical characterization studies of Yucca Mountain, Nevada: Reston, U. S. Geological Survey, p. 16.

Knott, J.R., 1998, Late Cenozoic tephrochronology, stratigraphy, geomorphology, and neotectonics of the western Black Mountains Piedmont, Death Valley, California; implications for the spatial and temporal evolution of the Death Valley fault zone: Ph.D. dissertation, University of California, Riverside.

Kruse, F.A., Lefkoff, A.B., and Dietz, J.B., 1993, Expert System-based mineral mapping in northern Death Valley, California/Nevada, using the Airborne Visible/Infrared Imaging Spectrometer (AVIRIS): Remote Sensing of Environment, v. 44, p. 309-336.

Lustig, L.K., 1965, Clastic sedimentation in Deep Springs Valley, California: U.S. Geological Survey Professional Paper 352-F, p. 192.

Machette, M.N., Johnson, M.L., and Slate, J.L., 2001, Quaternary and Late Pliocene Geology of the Death Valley Region: recent observations on tectonics, Stratigraphy, and lake cycles: U.S. Geological Survey Open-File Report 01-51, p. 246.

McKittrick, M.A., 1988, Surficial geologic map of the Resting Springs and Nopah Ranges, Inyo County California and Nye County, Nevada: U.S. Geological Survey Miscellaneous Field Studies Map MF-1941, 1 plate, scale 1:62,500.

Menges C. M., Taylor, E. M; Slate, J. L. and Dohrenwend, J. C., 1999, Strategy for mapping Quaternary surficial deposits in support of the Death Valley regional flow, in Slate, J., ed., Proceedings of Conference on Status of Geologic Research and Mapping in Death Valley National Park, Las Vegas, Nevada, April 9-11: U.S. Geological Survey Open-File Report: 99153 , p. $81-82$.

Menges, C.M., Taylor, E.T., Workman, J.B., and Jayko, A.S., 2001, Regional surficial-deposit mapping in the Death Valley area of California and Nevada in support of ground-water modeling: in Machette, M.N., Johnson, M.L. and Slate, J.L., eds, Quaternary and Late Pliocene Geology of the Death Valley region: Recent observations on Tectonics, Stratigraphy and Lake Cycles: U.S. Geological Survey Open-File Report 01-51, p. 151-166.

Miliaresis, G.C., 2001, Extraction of bajadas from digital eleation models and satellite imagery: Computers and Geosciences, v. 27, p. 1157-1168.

Miliaresis, G. C. and Argialas, D.P., 2000, Extraction and delineation of alluvial fans from digital elevation models and Landsat Thematic Mapper images: Photogrammetric engineering and remote sensing, v. 66, p. 1093-1101. 
Quade, J.; Mifflin, M. D.; Pratt, W. L., McCoy, W., and Burckle, L., 1995, Fossil spring deposits in the southern Great Basin and their implications for changes in water-table levels near Yucca Mountain, Nevada, during Quaternary time: Geological Society of America Bulletin, v.107, p. 213-230.

Reheis, M.C., and Noller, J.S., 1991, Aerial Photographic interpretation of lineaments and faults in Late Cenozoic deposits in the Eastern Part of the Benton Range 1:100,000 quadrangle and the Goldfield, Last Chance Range, Beatty and Death Valley Junction 1:100,000 quadrangles, Nevada and California: U.S. Geological Survey Open-File Report 90-41, scale 1:100,000.

Slate, J.L. and Berry, M.E., 1999, Preliminary surficial geologic map of the Beatty 30 X 60-minute quadrangle, Nevada-California, in Slate, J.L., ed., Proceedings of conference on status of geologic research and mapping, Death Valley National Park: U.S. Geological Survey, OpenFile Report 99-0153, pp.78-80, 1999.

Smith, G.I., Barczak, V.J., Moulton, G.F., and Liddicoat, J.C., 1983, Core KM-3, a surface-tobedrock record of late Cenozoic sedimentation in Searles Valley, California: U.S. Geological Survey Professional Paper 1256, p. 1-24.

Smith, M.O., Ustin, S.L., Adams, J.B., and Gillespie, A.R., 1990. Vegetation in deserts: I. A regional measure of abundance from multispectral images. Remote Sens. Environ. v. 31, p. 126.

Stearns, S.V., van der Horst, E., and Swihart, G., 1999, Hyperspectral mapping of borate minerals in Death Valley, California: Proceedings of the Thematic Conference on Geologic Remote Sensing, vol.13, no.1, pp.81-85.

Thiessen, R.L and Farr, T.G., 1996, GIS and remote sensing study of alluvial fans in Death Valley, Nevada: Proceedings of the Thematic Conference on Geologic Remote Sensing, vol.11, pp. I.299-I.308.

Workman, J.B. Menges, C.M. Page, W.R. Taylor, E.M. Ekren, E.B. Rowley, P.D. Dixon, G.L. Thompson, RA. and Wright, L.A., 2002, Death Valley Regional Flow System geologic map: U.S. Geological Survey Miscellaneous Field Studies map, MF-2381, scale 1:250,000.

Wright, L.A., and Troxel, B.W., 1993, Geologic map of the central and northern Funeral Mountains and adjacent areas, Death Valley region, southern California: U.S. Geological Survey Miscellaneous Investigations Series Map I-2305, scale 1:48,000. 


\section{Figures}

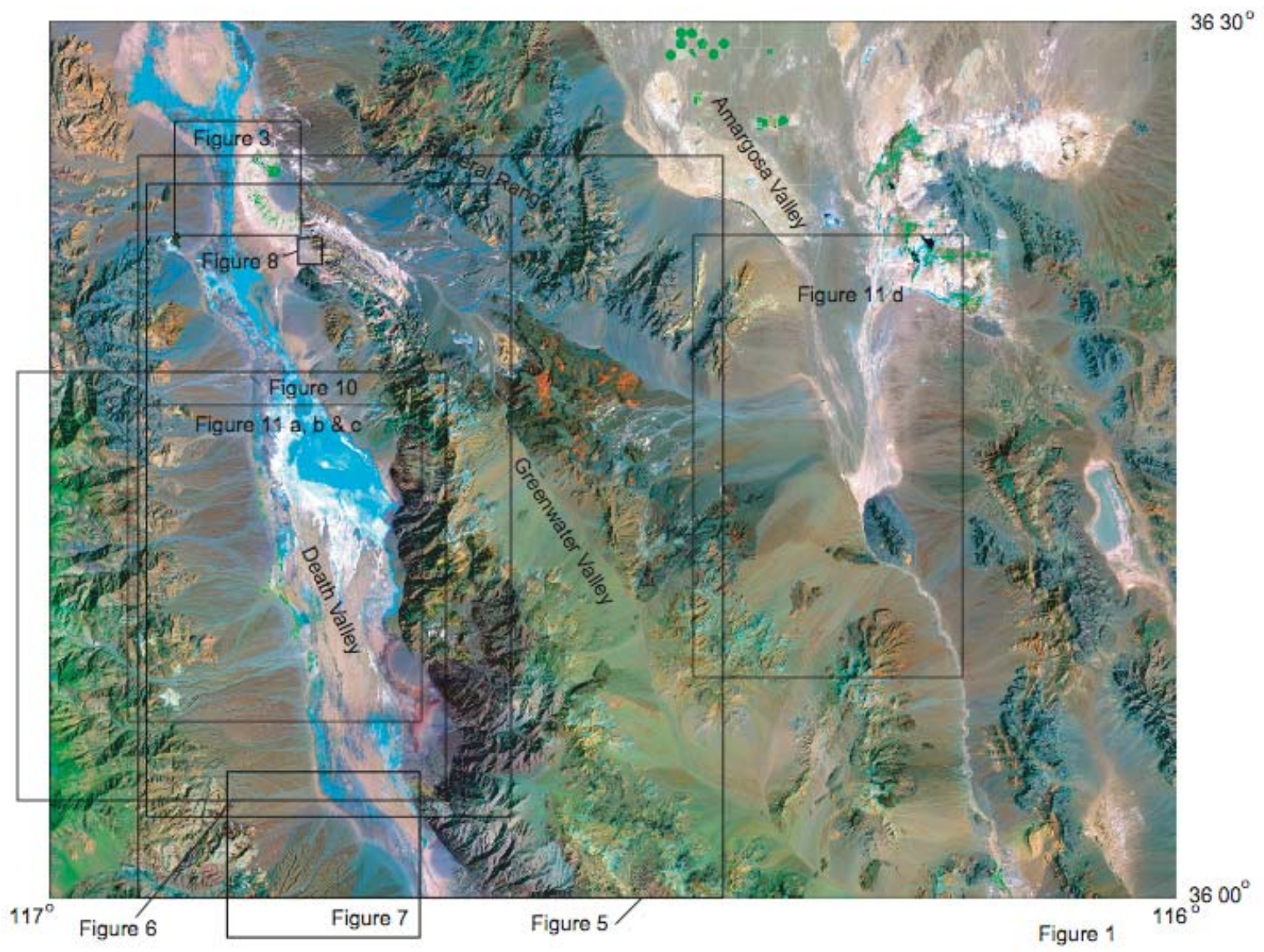

Figure 1. Landsat7 TM image scene, central Death Valley and southern Amargosa area showing location of Figures 3 to 11. 


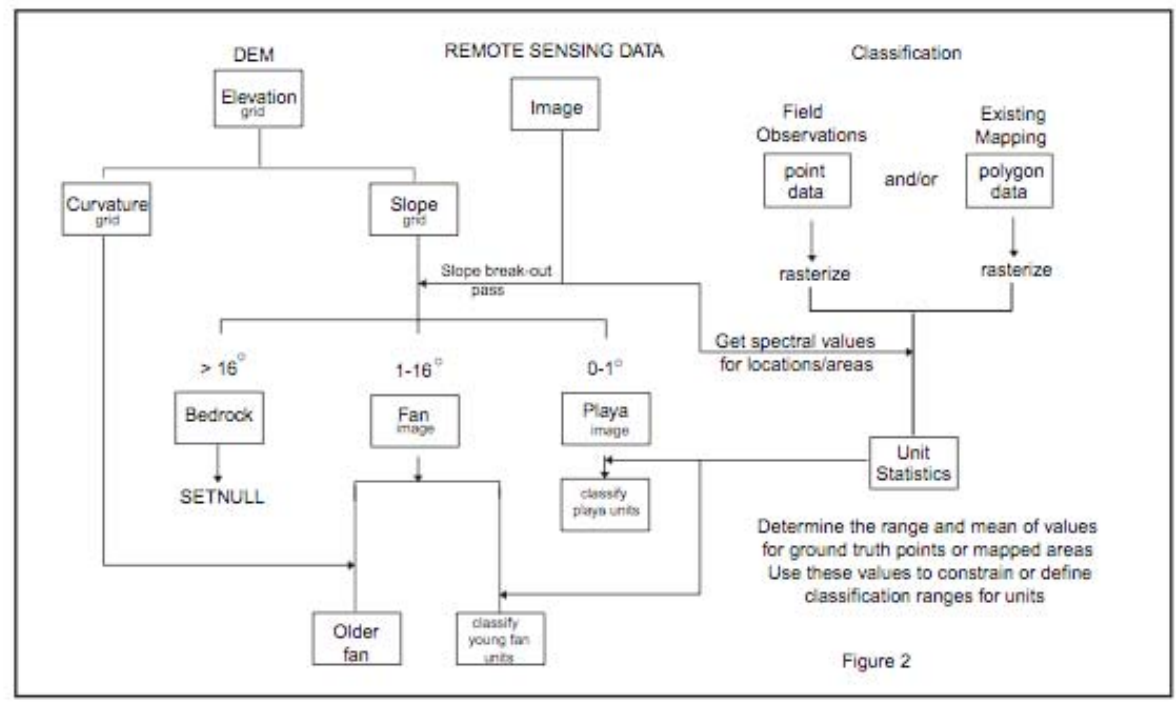

Figure 2. Flow chart diagram for producing digital surficial units map from remote sensing and DEM data. 


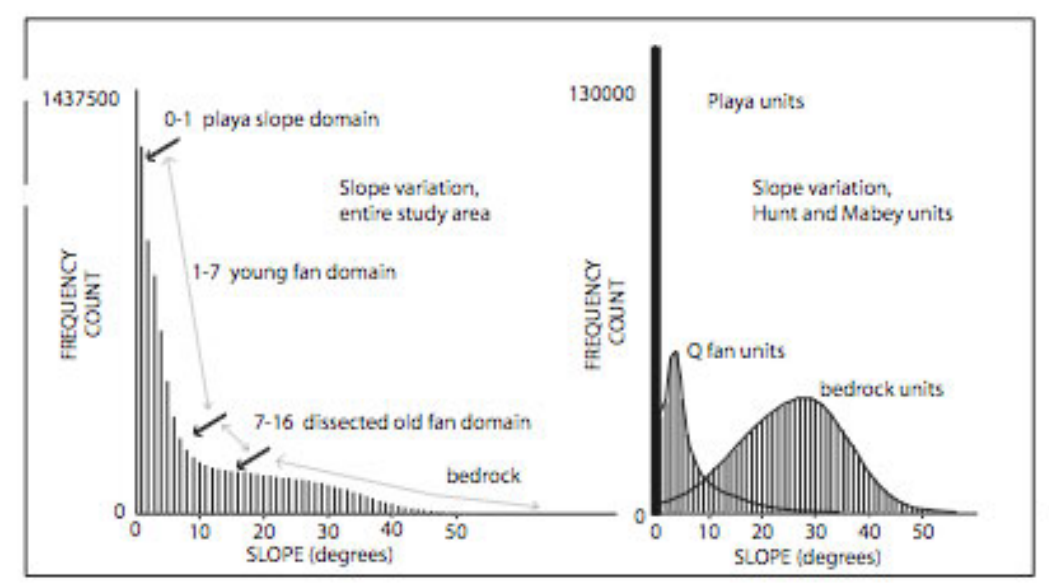

Figure
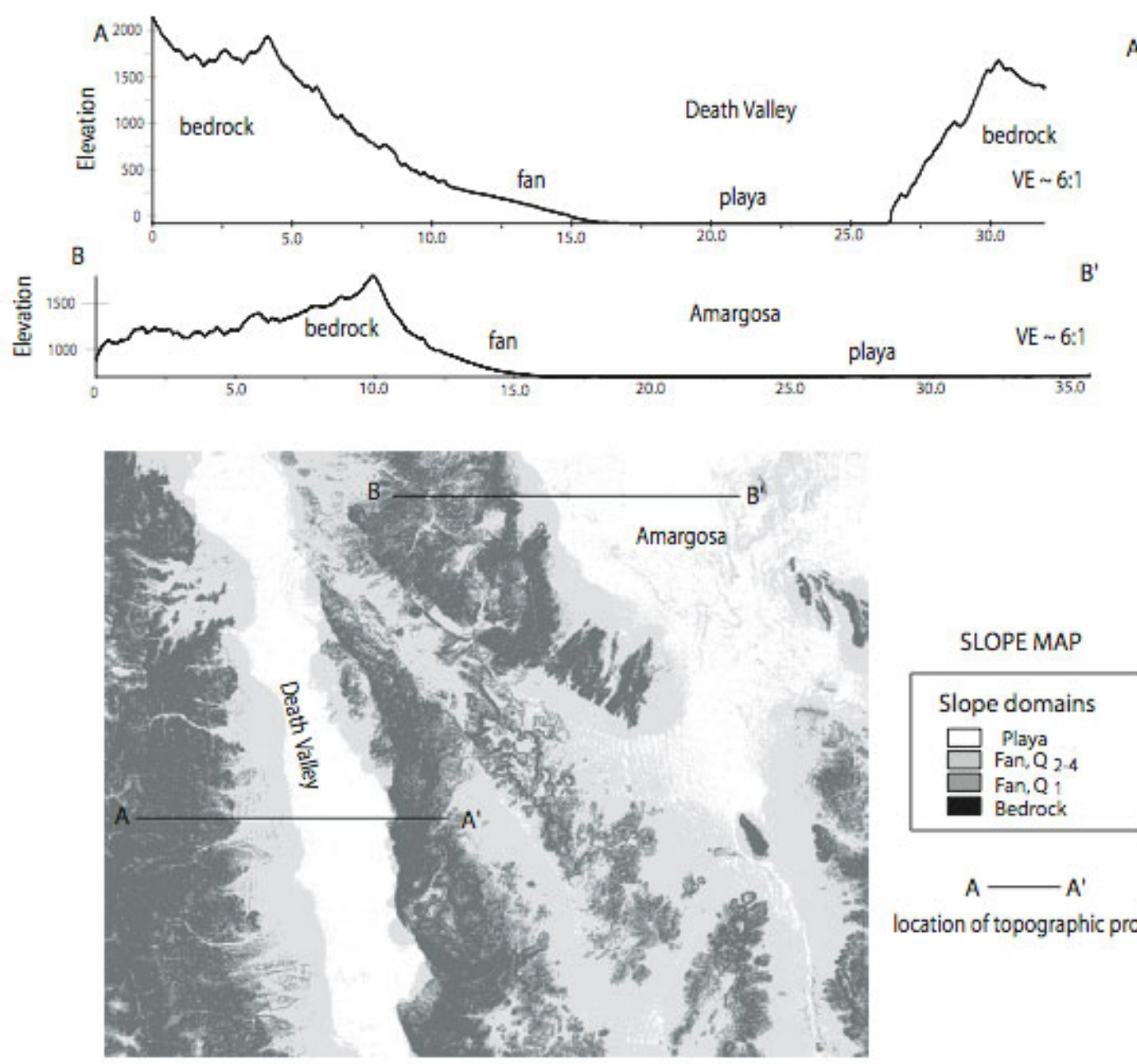

SLOPE MAP

Slope domains

$\square$ Playa

Fan, Q 2-4

Fan, $Q_{1}$

Bedrock

$A-A^{\prime}$

location of topographic profile

Figure 3. Histograms showing range in slope values for the bedrock, alluvial fan and playa domains; and slope map showing the distribution of bedrock terrain in ranges and range flanks generated from the slope grid. 


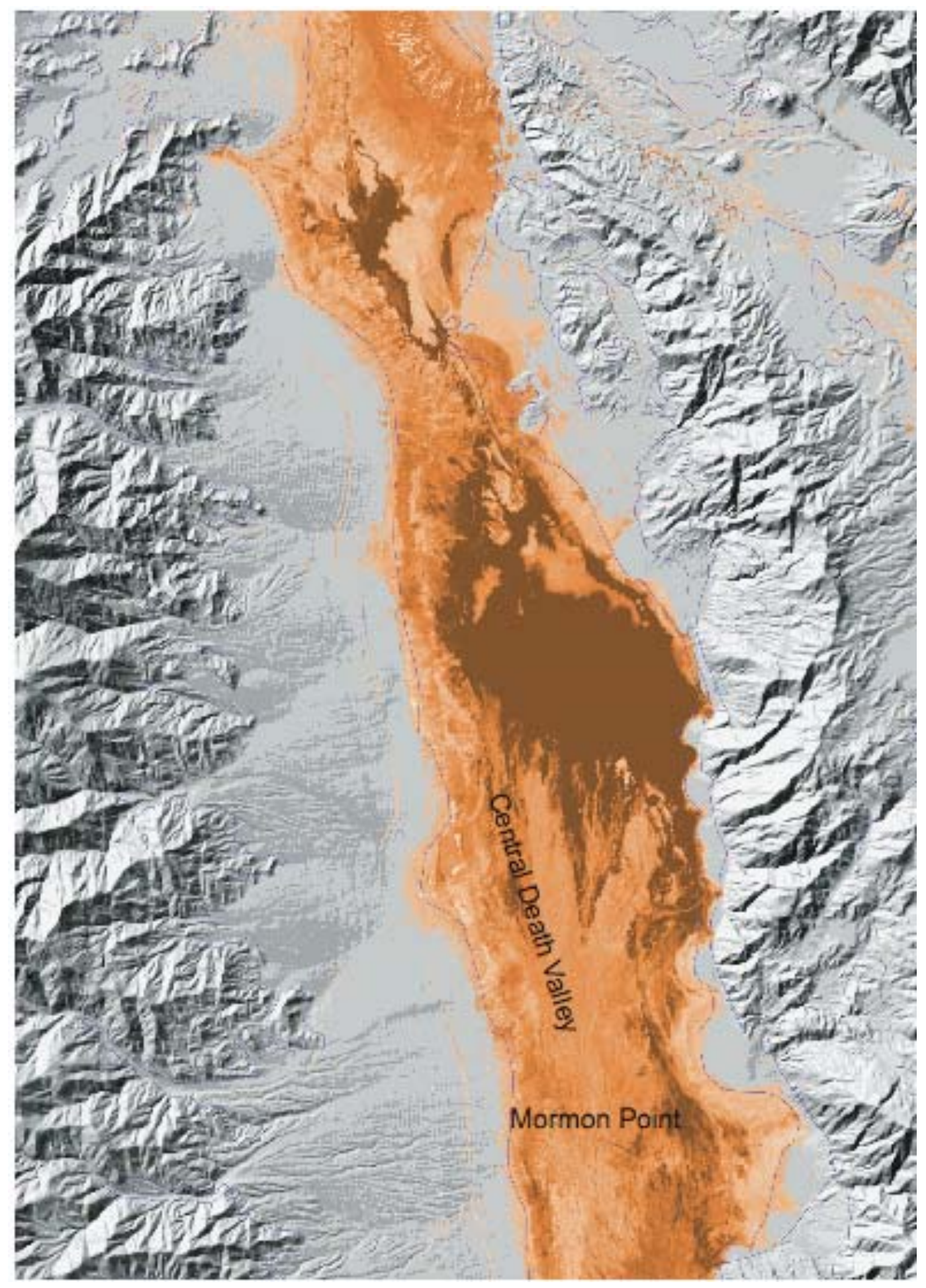

Figure 4. Map showing distribution of playa terrain generated from the slope grid and inset with SPOT $15 \mathrm{~m}$ monochromatic imagery compared with the geologic boundary of fans and bedrock from the Death Valley Regional Flow model, geologic layer, 1:250,000 scale (purple lines). 

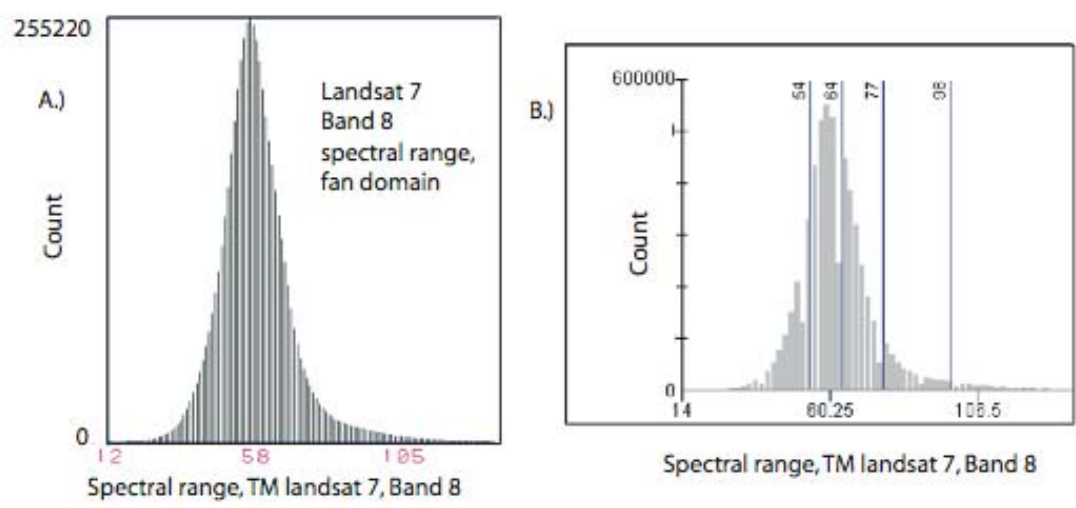

Natural steps, TM band 7,

fan domain delineated by

1-16 degree slope area.

(Unsupervised classification )
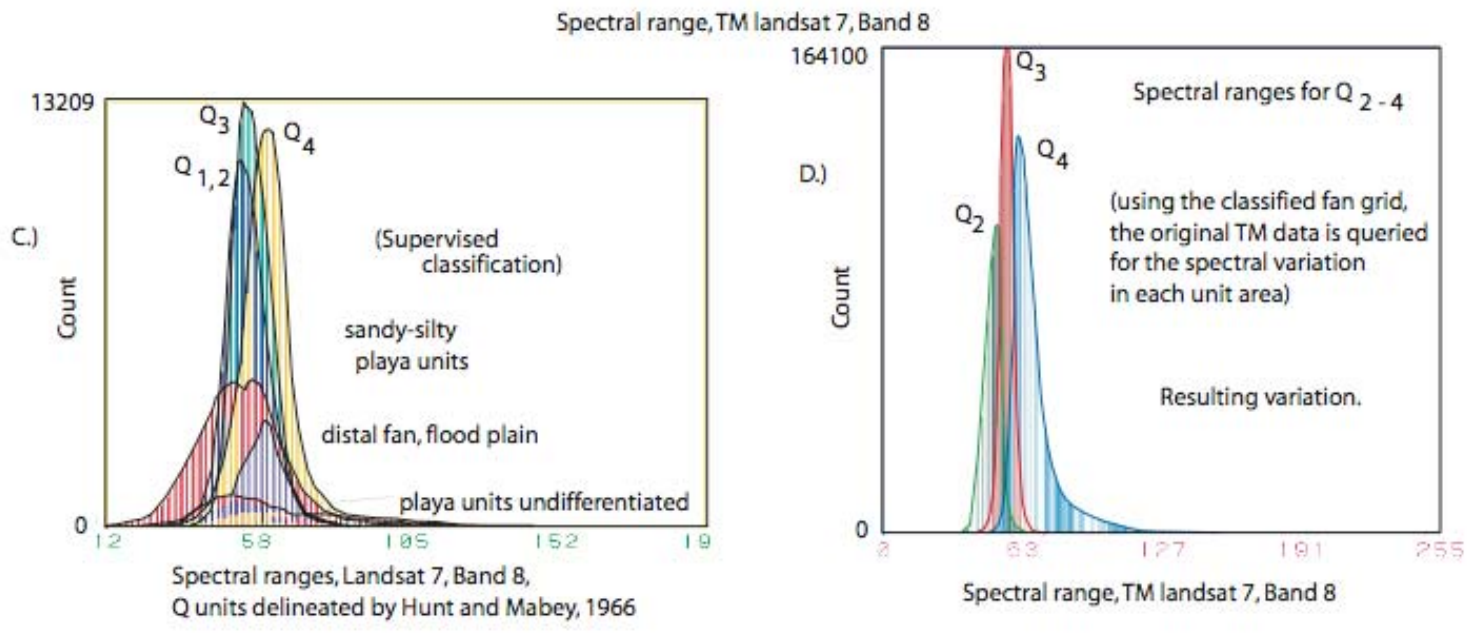

Figure 5a. Histograms of alluvial fan units, a.) entire fan domain, b.) natural breaks, c.) Hunt and Mabey (1966) Quaternary units, and d.) classified $Q_{2-4}$ units from thematic surfical deposits map. 


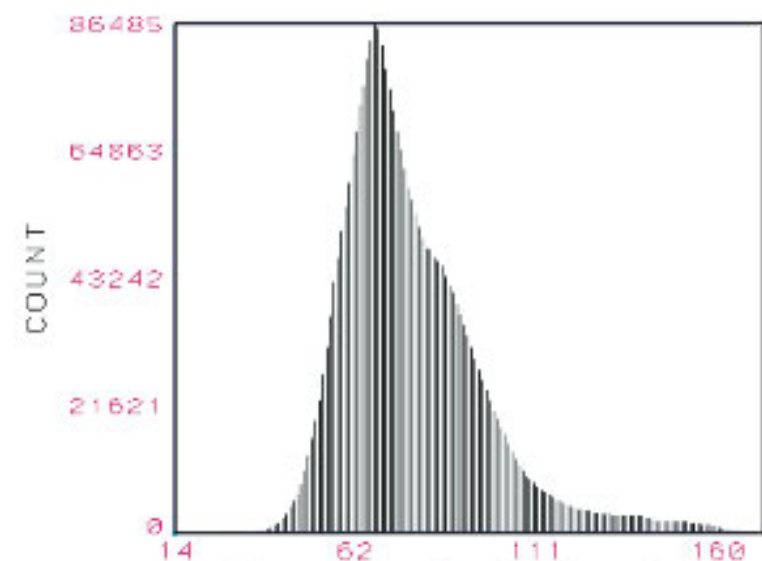

A. Spectral range for playa slope domain,

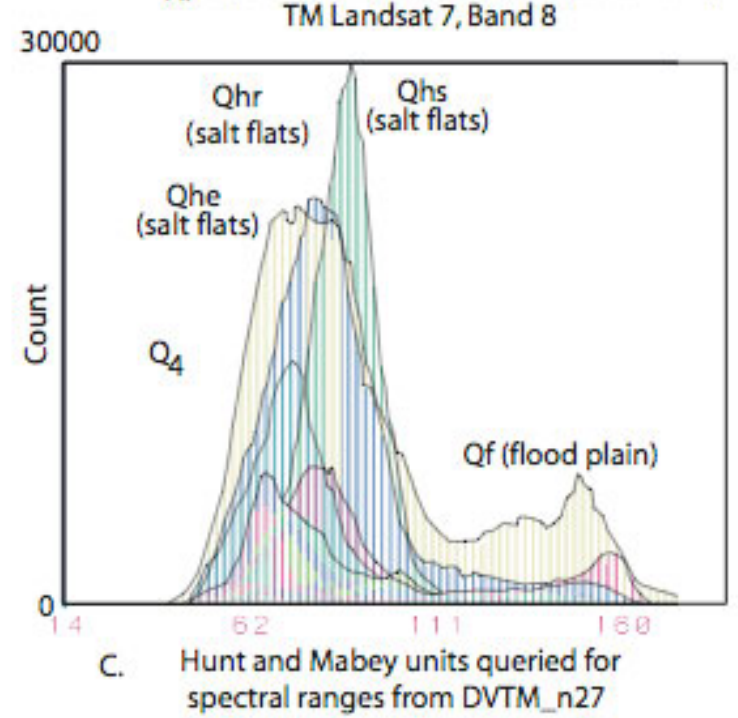

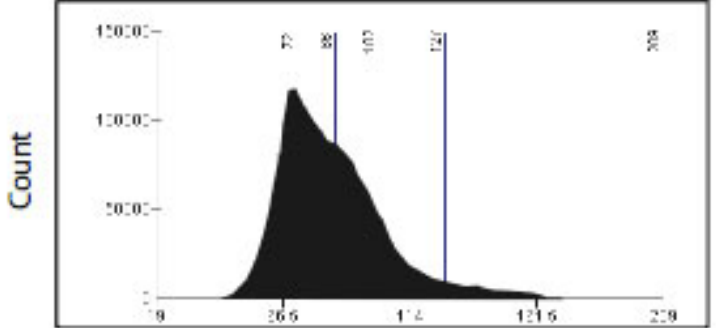

B. Natural steps, TM Landsat7, Band 8, playa domain defined by $0-1$ degree slope area.

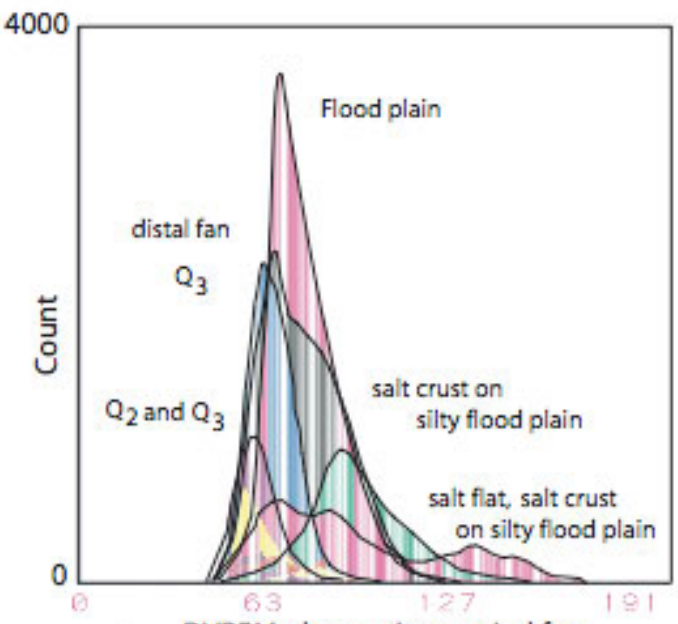

D. DVRFM playa units queried for spectral ranges from DVTM_n27

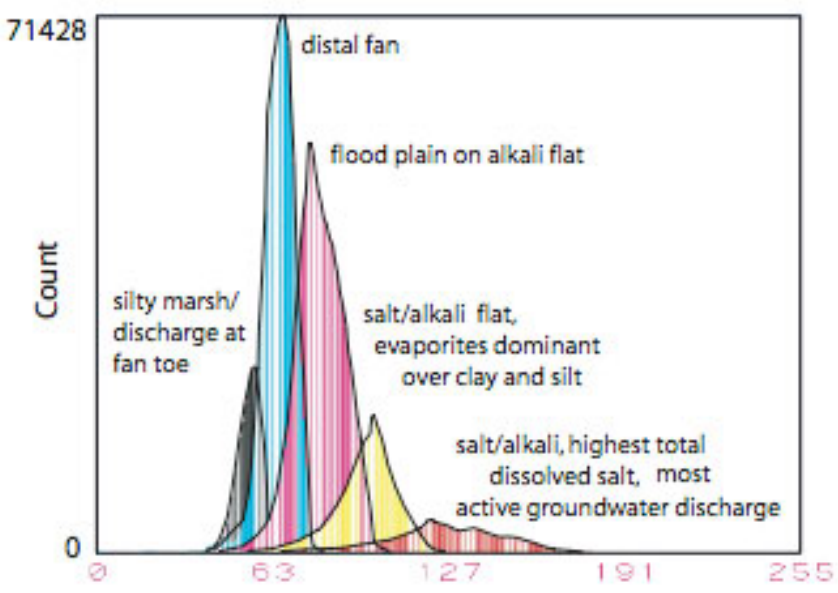

E.

Resulting spectral ranges for classified playa area

Figure 5b. Histograms of playa units, a.) entire fan domain, b.) natural breaks, c.) Hunt and Mabey (1966) Quaternary units, d.) classified playa units from Death Valley Regional Flow Model, ande.) classified playa units from thematic surfical deposits map. 


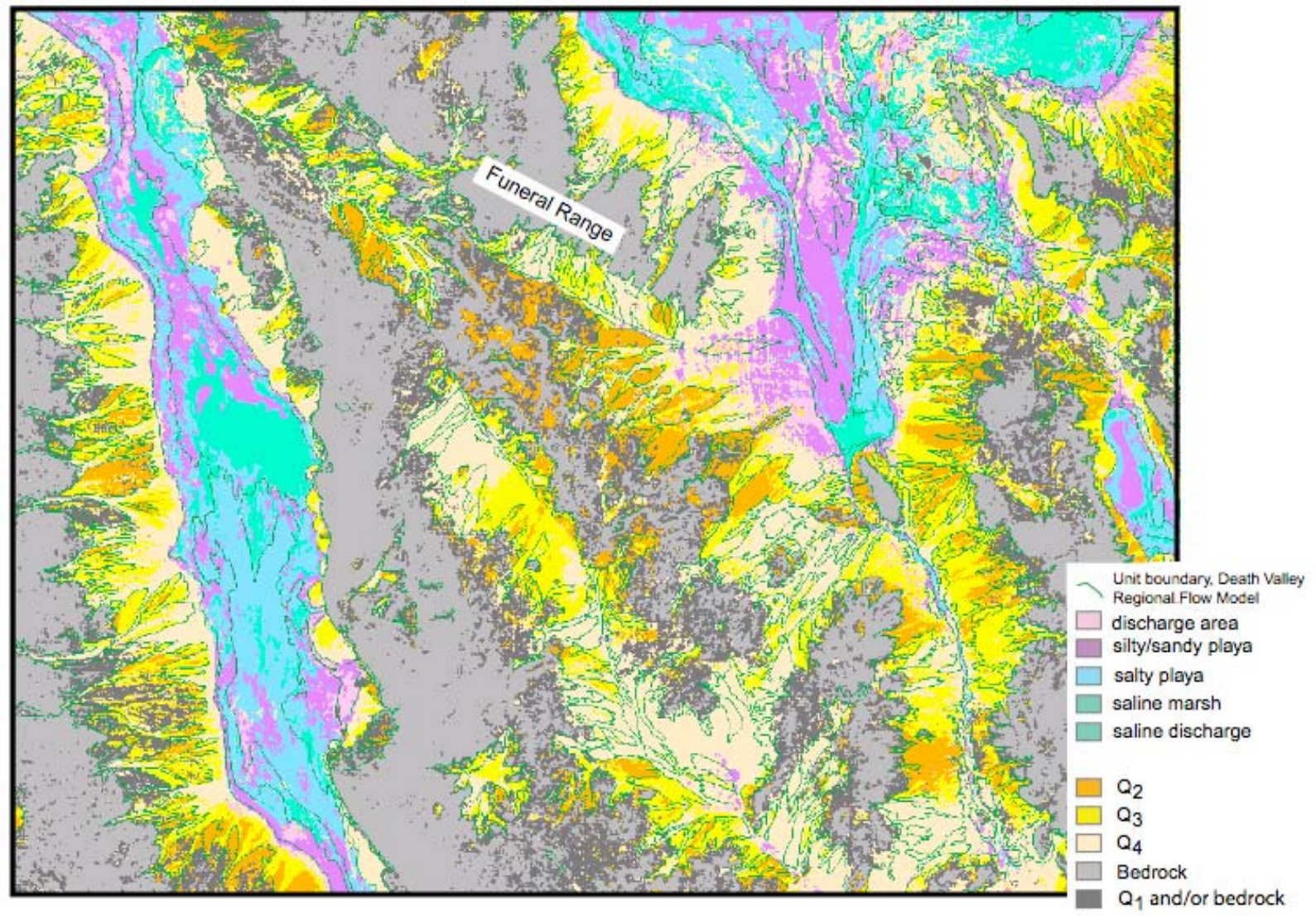

Figure 6. Thematic surfical deposits map with unit boundaries from the Death Valley Regional Goundwater Flow model overlain for comparison. Classification ranges for this map was selected to best fit the ground truth and Workman and others (2002). 

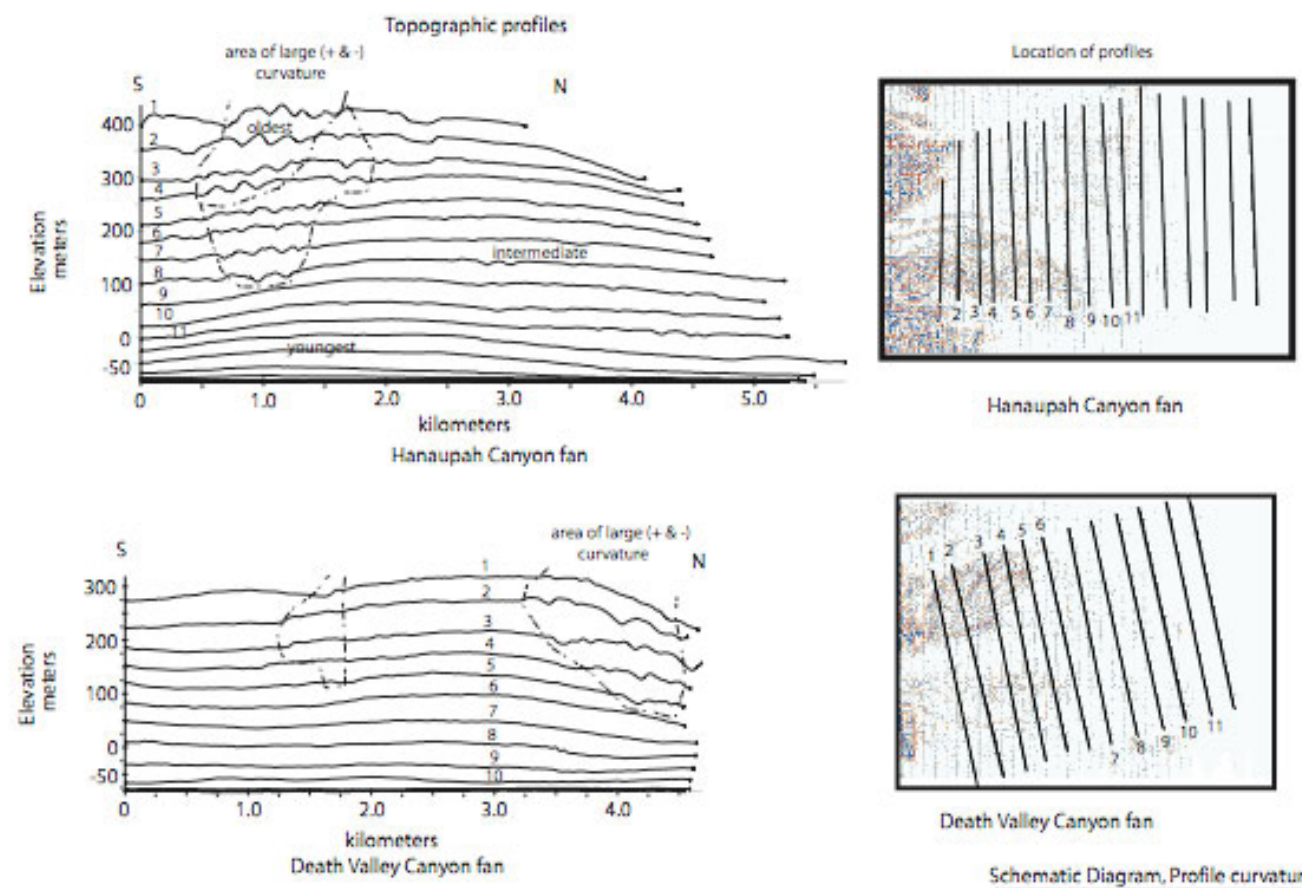

Death Valley Canyon fan

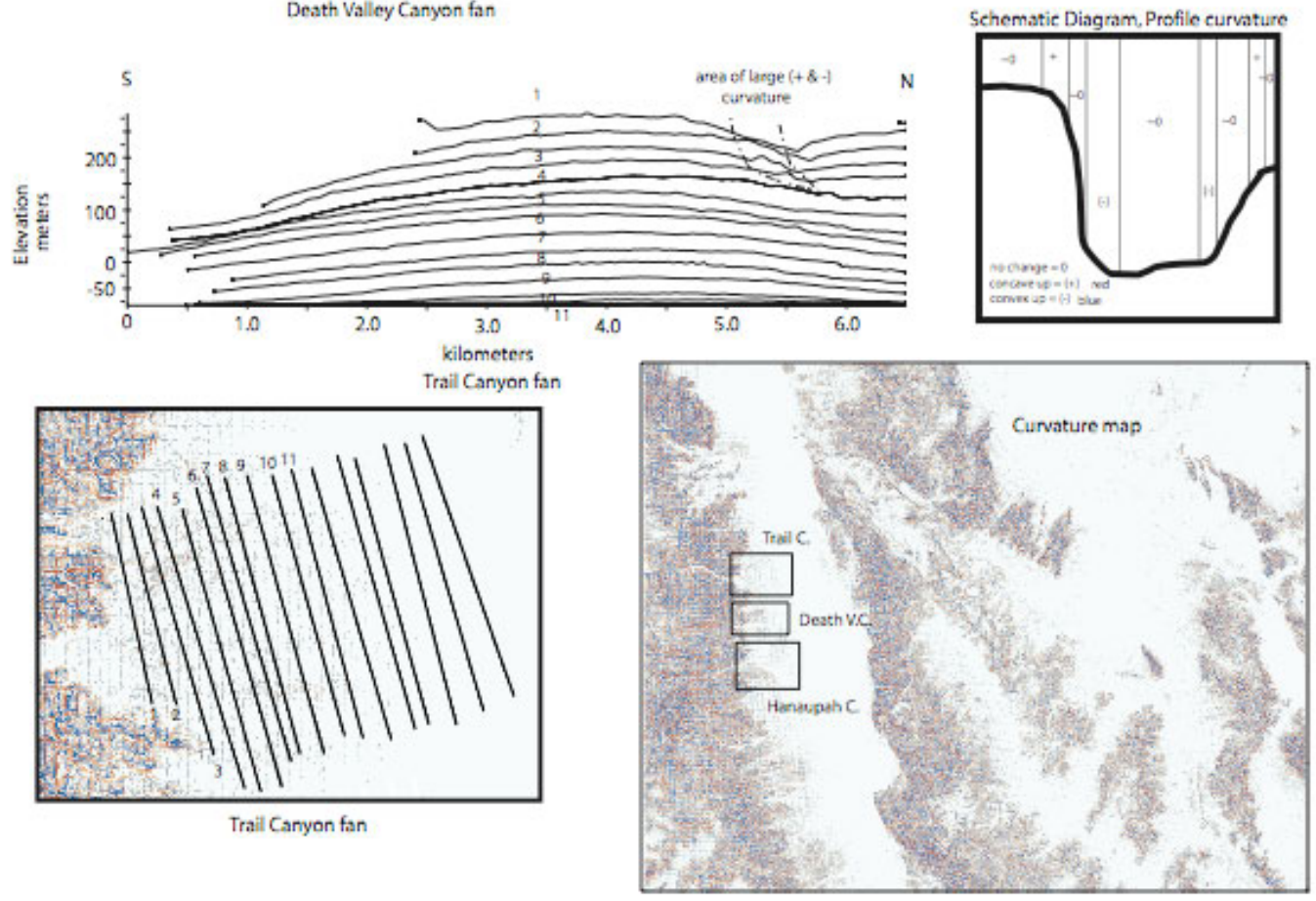

Figure 7. Topographic profiles through selected fan on the west side of Death Valley showing areas of fan with extreme profile curfature. Numbered profiles on the curvature maps correspond to numbers on the topographic profiles. Inset schematic diagram showing example of areas underlain by $(+),(-)$ and $(0)$ profile curvature. 


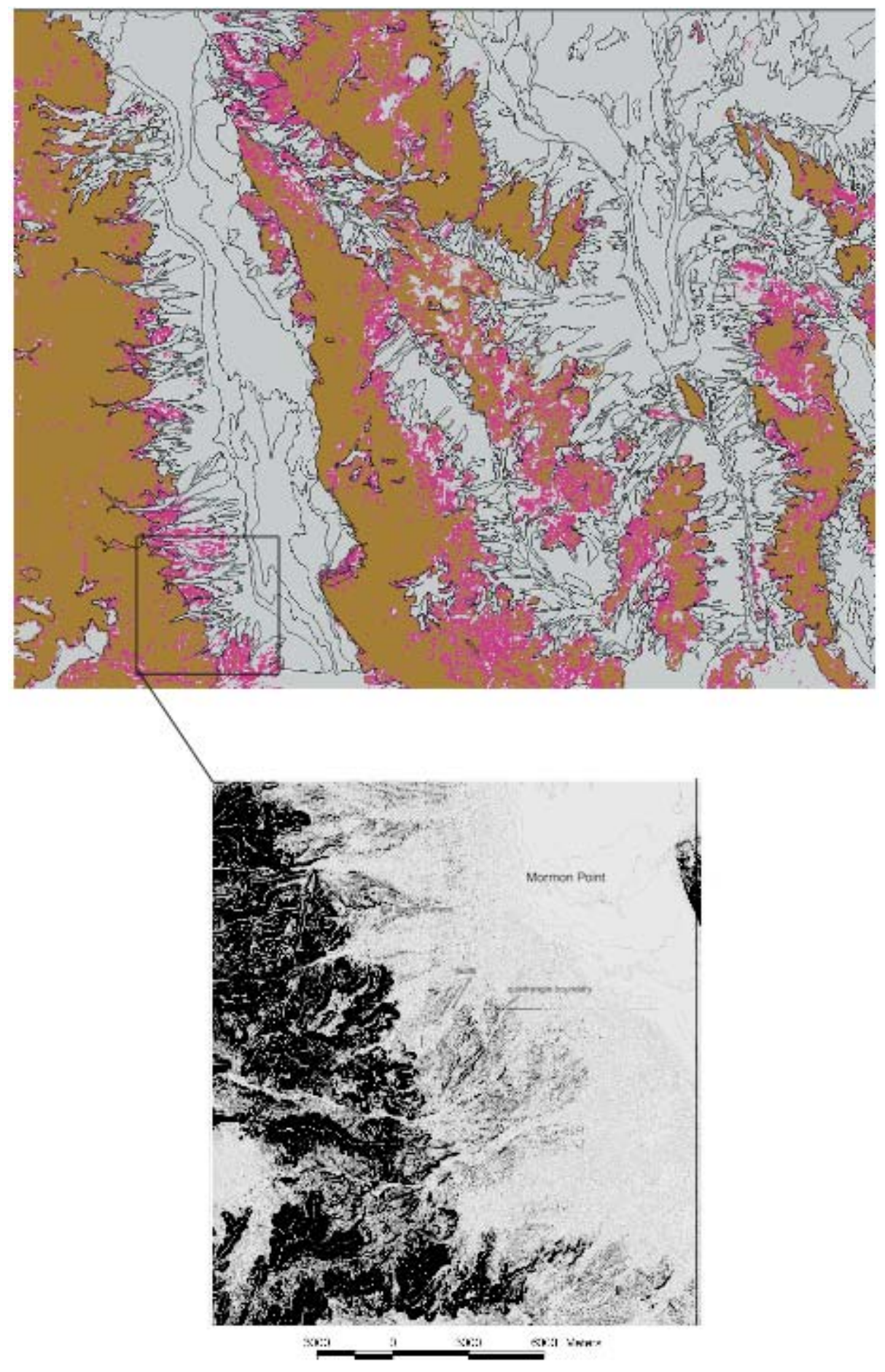

Figure 8. Mapshowing area underlain by bedrock and dissected fan derived from areas of slope greater than 16 degress and extreme curvature for the study area. Inset map showing an example of an older Q1 fan unit on the west side of Death Valley near Six Spring Canyon, west of Mormon Point, illustrating contrast in dissection enhanced by curvature. Very dark areas are bedrock, medium grays dissected fan surfaces and light gray areas are playa and Q2-Q4 areas of alluvial fans. 

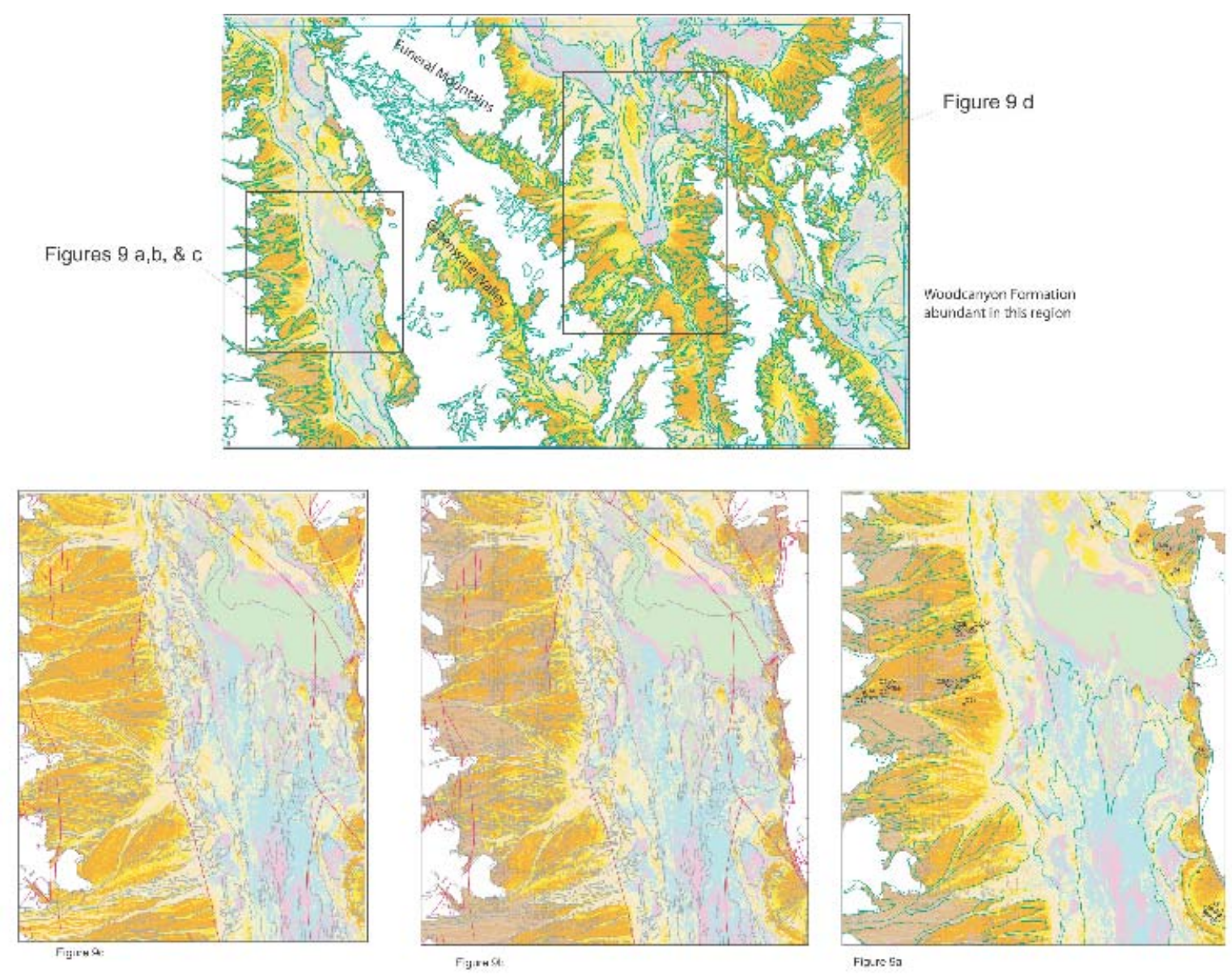

Figure 9 Area of the Death Valley Junction 1:100,000 map showing surficial basin units mapped from TM Landsat 7 Band 8 data and DEM data with units from Workman et al (2002) shown in green lines. Classification values for this version of the surficial deposits map were selected for agreement with Hunt and Mabey (1966). Locations of figures $9 \mathrm{a}-\mathrm{d}$ shown by inset boxes.

9a. Surficial basin units in the central Death Valley area discriminated by classification of TM Landsat 7 Band 8 data and DEM data with point localities and units discriminated in the field (Menges et al, 2001) and Workman et al, 2002) shown in green lines.

9b. Surficial basin units in the central Death Valley area discriminated by classification of TM Landsat 7 Band 8 data and DEM data with unit boundaries mapped by Hunt and Mabey (1966) shown in gray lines.

9c. Surficial basin units in the central Death Valley area discriminated by classification of TM Landsat7 Band 8 data and DEM data, excluding Q1 alluvial fan unit with unit boundaries mapped by Hunt and Mabey (1966) shown in gray lines

9d. Surficial basin units in the southern Amargosa area discriminated by classification of TM 7 Band 8 data and DEM data with point localities and units discriminated in the field (Menges et al, 2001) and Workman et al, 2002). 


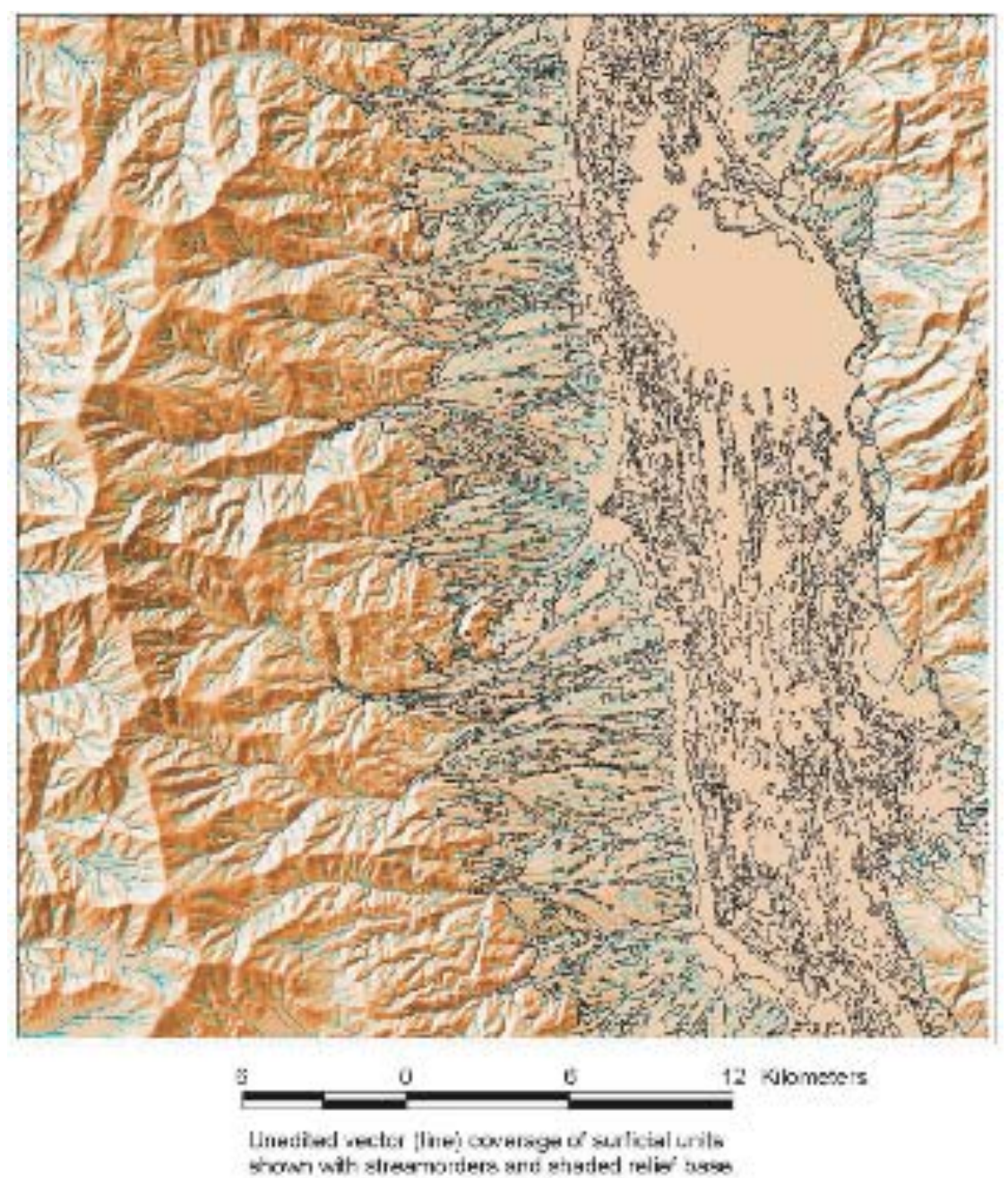

Figure 10. Map showing the unit boundaries from the thematic surficial deposits map overlain on a shaded relief base with digitally generated stream channels. 


\section{Table 1. Summary of selected surficial deposit units mapped in DVRFS area.}

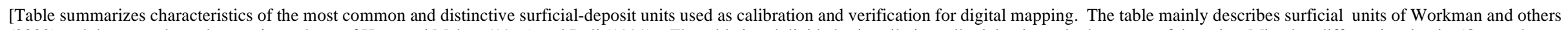

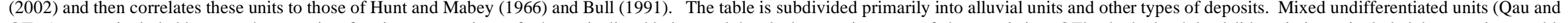

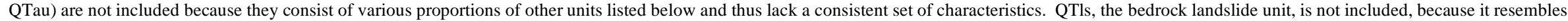

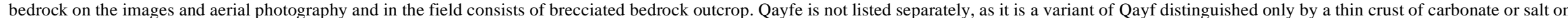
the surface of the deposit (see unit descriptions). The first three columns list map nomenclature, general character, and age range estimated from correlations with specific local to regional scale studies with

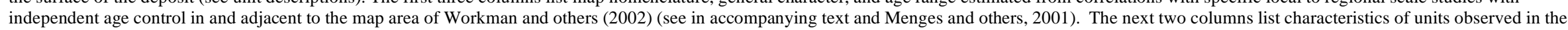

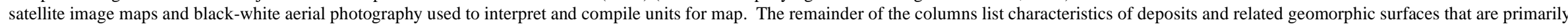
based on observations from field traverses of Workman and others (2002). N/A indicates Not Applicable.]

\begin{tabular}{|c|c|c|c|c|c|c|c|c|c|c|c|c|c|}
\hline \multicolumn{3}{|c|}{ Units $^{1}$} & \multirow[b]{2}{*}{ Type $^{2}$} & \multirow[b]{2}{*}{$\mathrm{Age}^{3}$} & \multicolumn{2}{|c|}{ Image/Photo Characteristics ${ }^{4}$} & \multirow[b]{2}{*}{$\begin{array}{l}\text { Physiographic } \\
\text { Position }^{5}\end{array}$} & \multirow[b]{2}{*}{$\begin{array}{c}\text { Internal } \\
\text { Dissection }\end{array}$} & \multicolumn{2}{|c|}{ Surface Characteristics ${ }^{7}$} & \multirow[b]{2}{*}{ Varnish $^{8}$} & \multirow[b]{2}{*}{$\begin{array}{c}\text { General Soil } \\
\text { Characteristics }\end{array}$} & \multirow[b]{2}{*}{$\begin{array}{c}\text { Typical Grain } \\
\text { Size }^{10}\end{array}$} \\
\hline $\begin{array}{l}\text { Workman } \\
\text { and } \\
\text { others }\end{array}$ & $\begin{array}{l}\text { Hunt } \\
\text { and } \\
\text { Mabey }\end{array}$ & Bull & & & Landsat 7 Images & $\begin{array}{l}\text { Panchromatic } \\
\text { Satellite and } \\
\text { Aerial } \\
\text { Photography }\end{array}$ & & & Pavement & $\begin{array}{l}\text { Bar and } \\
\text { Swale }\end{array}$ & & & \\
\hline & $\underline{\text { Alluvial }}$ & & & & & & & & & & & & \\
\hline Qc & Qg4, Qf & Q4 & $\begin{array}{l}\text { Channel } \\
\text { alluvium }\end{array}$ & Recent & $\begin{array}{l}\text { Variable, light } \\
\text { colored to white; } \\
\text { light blue where } \\
\text { salt encrusted }\end{array}$ & $\begin{array}{l}\text { White to light } \\
\text { gray }\end{array}$ & $\begin{array}{l}\text { Intrarange valleys, } \\
\text { piedmonts, and } \\
\text { axial basin } \\
\text { drainages }\end{array}$ & $\begin{array}{l}\text { None to minor } \\
\text { thalweg } \\
\text { incision }\end{array}$ & None & $\begin{array}{l}\text { Unmodified } \\
\text { primary }\end{array}$ & $\begin{array}{l}\text { None (only } \\
\text { inherited) }\end{array}$ & None & $\begin{array}{l}\text { Variable, from } \\
\text { mixed gravel } \\
\text { to fine sand }\end{array}$ \\
\hline Qay & Qg3 & $\begin{array}{c}\mathrm{Q3} \\
(\mathrm{a}, \mathrm{b}, \mathrm{c})\end{array}$ & $\begin{array}{l}\text { Medium - } \\
\text { to coarse- } \\
\text { grained } \\
\text { alluvium }\end{array}$ & $\begin{array}{l}\text { Recent to } \\
\text { Holocene, } \\
\text { locally latest } \\
\text { Pleistocene }\end{array}$ & $\begin{array}{c}\text { Light to dark } \\
\text { colors, including } \\
\text { browns; rough to } \\
\text { medium textures }\end{array}$ & $\begin{array}{l}\text { Light to } \\
\text { medium gray }\end{array}$ & $\begin{array}{l}\text { Proximal to distal } \\
\text { piedmonts, } \\
\text { terraces, coarse } \\
\text { axial drainages }\end{array}$ & $\begin{array}{l}\text { None to minor } \\
\text { (mostly } \\
\text { primary) }\end{array}$ & $\begin{array}{l}\text { None to } \\
\text { weak, locally } \\
\text { moderate }\end{array}$ & $\begin{array}{l}\text { Unmodified } \\
\text { to faint (but } \\
\text { discernable) }\end{array}$ & $\begin{array}{l}\text { None to } \\
\text { moderate }\end{array}$ & $\begin{array}{c}\text { None to weak } \\
\text { (cambic and } \\
\text { Stage I calcic } \\
\text { horizons) }\end{array}$ & $\begin{array}{l}\text { Coarse to fine } \\
\text { gravel and } \\
\text { sand }\end{array}$ \\
\hline Qayo & & Q3a,b & $\begin{array}{l}\text { Medium - } \\
\text { to coarse- } \\
\text { grained } \\
\text { alluvium }\end{array}$ & $\begin{array}{l}\text { Middle to } \\
\text { early } \\
\text { Holocene, } \\
\text { locally latest } \\
\text { Pleistocene }\end{array}$ & $\begin{array}{l}\text { Medium to dark } \\
\text { colors, including } \\
\text { browns; medium } \\
\text { textures }\end{array}$ & $\begin{array}{l}\text { Medium to dark } \\
\text { grays }\end{array}$ & $\begin{array}{l}\text { Proximal to distal } \\
\text { piedmonts, terraces }\end{array}$ & None to minor & $\begin{array}{l}\text { Weak to } \\
\text { locally } \\
\text { moderate }\end{array}$ & $\begin{array}{c}\text { Faint, but } \\
\text { discernable }\end{array}$ & $\begin{array}{l}\text { Weak to } \\
\text { moderate }\end{array}$ & $\begin{array}{l}\text { Weak (cambic } \\
\text { and Stage I calcic } \\
\text { horizons) }\end{array}$ & $\begin{array}{l}\text { Coarse to fine } \\
\text { gravel and } \\
\text { sand }\end{array}$ \\
\hline Qayf & & & $\begin{array}{c}\text { Fine- } \\
\text { grained } \\
\text { alluvium }\end{array}$ & $\begin{array}{l}\text { Recent to } \\
\text { Holocene, } \\
\text { locally latest } \\
\text { Pleistocene }\end{array}$ & $\begin{array}{l}\text { Light to medium } \\
\text { colors, including } \\
\text { brown; light blue } \\
\text { where salt } \\
\text { encrusted; } \\
\text { smooth to } \\
\text { medium textures }\end{array}$ & $\begin{array}{l}\text { White and light } \\
\text { to medium } \\
\text { grays }\end{array}$ & $\begin{array}{c}\text { Mostly fine- } \\
\text { grained axial } \\
\text { drainages and } \\
\text { interior alluvial } \\
\text { plains, some distal } \\
\text { piedmonts }\end{array}$ & $\begin{array}{l}\text { None to very } \\
\text { minor }\end{array}$ & $\begin{array}{l}\text { None to } \\
\text { weak, locally } \\
\text { moderate }\end{array}$ & None to faint & $\begin{array}{l}\text { None to } \\
\text { moderate }\end{array}$ & $\begin{array}{c}\text { None to weak } \\
\text { (cambic and } \\
\text { Stage I carbonate } \\
\text { horizons) }\end{array}$ & $\begin{array}{l}\text { Sand, silt, } \\
\text { minor fine } \\
\text { gravel }\end{array}$ \\
\hline Qao & Qg2 & Q2b,c & $\begin{array}{l}\text { Medium- } \\
\text { to coarse- } \\
\text { grained } \\
\text { alluvium }\end{array}$ & Pleistocene & $\begin{array}{l}\text { Light to dark } \\
\text { colors, including } \\
\text { brown to reddish } \\
\text { brown; smooth to } \\
\text { medium textures }\end{array}$ & $\begin{array}{l}\text { Light to } \\
\text { medium grays }\end{array}$ & $\begin{array}{l}\text { Proximal to medial, } \\
\text { and locally distal, } \\
\text { piedmonts; terraces } \\
\text { in intrarange } \\
\text { valleys }\end{array}$ & $\begin{array}{l}\text { Commonly } \\
\text { moderate to } \\
\text { strong; locally } \\
\text { minor }\end{array}$ & $\begin{array}{l}\text { Strong to } \\
\text { moderate; } \\
\text { present on } \\
\text { interfluves } \\
\text { where } \\
\text { dissected }\end{array}$ & None & $\begin{array}{l}\text { Strong to } \\
\text { moderate }\end{array}$ & $\begin{array}{l}\text { Strong to } \\
\text { moderate; } \\
\text { includes argillic } \\
\text { and (or) Stage II- } \\
\text { IV calcic to } \\
\text { petrocalcic } \\
\text { horizons) }\end{array}$ & $\begin{array}{l}\text { Coarse to fine } \\
\text { gravel and } \\
\text { sand }\end{array}$ \\
\hline
\end{tabular}




\begin{tabular}{|c|c|c|c|c|c|c|c|c|c|c|c|c|c|}
\hline & Units $^{1}$ & & \multirow[b]{2}{*}{ Type $^{2}$} & \multirow[b]{2}{*}{$\mathrm{Age}^{3}$} & \multicolumn{2}{|c|}{ Image/Photo Characteristics ${ }^{4}$} & \multirow[b]{2}{*}{$\begin{array}{l}\text { Physiographic } \\
\text { Position }^{5}\end{array}$} & \multirow[b]{2}{*}{$\begin{array}{c}\text { Internal } \\
\text { Dissection }^{6}\end{array}$} & \multicolumn{2}{|c|}{ Surface Characteristics $^{7}$} & \multirow[b]{2}{*}{ Varnish $^{8}$} & \multirow[b]{2}{*}{$\begin{array}{c}\text { General Soil } \\
\text { Characteristics }{ }^{9}\end{array}$} & \multirow[b]{2}{*}{$\begin{array}{l}\text { Typical Grain } \\
\text { Size }^{10}\end{array}$} \\
\hline $\begin{array}{l}\text { Workman } \\
\text { and } \\
\text { others }\end{array}$ & $\begin{array}{l}\text { Hunt } \\
\text { and } \\
\text { Mabey }\end{array}$ & Bull & & & Landsat 7 Images & $\begin{array}{l}\text { Panchromatic } \\
\text { Satellite and } \\
\text { Aerial } \\
\text { Photography }\end{array}$ & & & Pavement & $\begin{array}{l}\text { Bar and } \\
\text { Swale }\end{array}$ & & & \\
\hline QTa & QTg1 & Q2a, Q1 & $\begin{array}{l}\text { Medium - } \\
\text { to coarse- } \\
\text { grained } \\
\text { alluvium }\end{array}$ & $\begin{array}{l}\text { Early- middle } \\
\text { Pleistocene to } \\
\text { Pliocene }\end{array}$ & $\begin{array}{l}\text { Light to medium } \\
\text { colors, possible } \\
\text { light brown tint; } \\
\text { smooth to } \\
\text { medium textures }\end{array}$ & $\begin{array}{l}\text { Light to } \\
\text { medium grays }\end{array}$ & $\begin{array}{l}\text { Proximal to locally } \\
\text { medial piedmonts; } \\
\text { range-front } \\
\text { embayments; } \\
\text { intrarange valleys }\end{array}$ & $\begin{array}{l}\text { Commonly } \\
\text { strong and } \\
\text { deep (ballena } \\
\text { topography) }\end{array}$ & $\begin{array}{l}\text { None to } \\
\text { weak, } \\
\text { commonly } \\
\text { with } \\
\text { carbonate } \\
\text { chips }\end{array}$ & None & $\begin{array}{l}\text { None to } \\
\text { weakly } \\
\text { preserved }\end{array}$ & $\begin{array}{c}\text { Strong to } \\
\text { moderate; } \\
\text { variably eroded } \\
\text { Stage III-V } \\
\text { petrocalcic where } \\
\text { preserved }\end{array}$ & $\begin{array}{l}\text { Coarse to fine } \\
\text { gravel and } \\
\text { sand }\end{array}$ \\
\hline & $\underline{\text { Other }}$ & & & & & & & & & & & & \\
\hline Qlc & $\mathrm{L}$ & & $\begin{array}{l}\text { Medium } \\
\text { to coarse- } \\
\text { grained } \\
\text { lacustrine } \\
\text { deposits }\end{array}$ & $\begin{array}{l}\text { Late to middle } \\
\text { Pleistocene }\end{array}$ & $\begin{array}{l}\text { Light to dark } \\
\text { colors, including } \\
\text { brown to reddish } \\
\text { brown; smooth to } \\
\text { medium textures }\end{array}$ & $\begin{array}{l}\text { Light to } \\
\text { medium grays }\end{array}$ & $\begin{array}{l}\text { Mostly medial to } \\
\text { distal piedmonts }\end{array}$ & $\begin{array}{l}\text { Commonly } \\
\text { moderate to } \\
\text { strong; locally } \\
\text { minor }\end{array}$ & $\begin{array}{l}\text { Strong to } \\
\text { moderate, } \\
\text { but present } \\
\text { on } \\
\text { interfluves } \\
\text { where } \\
\text { dissected }\end{array}$ & None & $\begin{array}{l}\text { Strong to } \\
\text { moderate }\end{array}$ & $\begin{array}{l}\text { Strong to } \\
\text { moderate; } \\
\text { includes argillic } \\
\text { and (or) Stage II- } \\
\text { IV calcic to } \\
\text { petrocalcic } \\
\text { horizons) }\end{array}$ & $\begin{array}{l}\text { Medium- to } \\
\text { fine gravel and } \\
\text { sand } \\
\text { (moderately to } \\
\text { well sorted) }\end{array}$ \\
\hline QTsf & $\begin{array}{l}\text { QTg1, } \\
\text { Tf }\end{array}$ & & $\begin{array}{c}\text { Fine- } \\
\text { grained } \\
\text { lacustrine } \\
\text {, inactive } \\
\text { playa, } \\
\text { and } \\
\text { alluvial } \\
\text { deposits }\end{array}$ & $\begin{array}{l}\text { Pleistocene to } \\
\text { Pliocene }\end{array}$ & $\begin{array}{l}\text { White to light } \\
\text { colors; medium to } \\
\text { smooth textures }\end{array}$ & $\begin{array}{l}\text { White to light } \\
\text { grays }\end{array}$ & $\begin{array}{l}\text { Variable, including } \\
\text { proximal to distal } \\
\text { fans and basin } \\
\text { interiors }\end{array}$ & $\begin{array}{l}\text { Moderate to } \\
\text { strong, in } \\
\text { dissected } \\
\text { basins; locally } \\
\text { none }\end{array}$ & N/A & N/A & N/A & $\begin{array}{l}\text { Local buried } \\
\text { paleosols, } \\
\text { variable weak to } \\
\text { strong } \\
\text { development }\end{array}$ & $\begin{array}{l}\text { Silt, clay, fine } \\
\text { sand; local } \\
\text { gravel } \\
\text { interbeds }\end{array}$ \\
\hline Qp & $\begin{array}{l}\text { Qc, Qs, } \\
\text { Qh }\end{array}$ & & $\begin{array}{l}\text { Active } \\
\text { playa and } \\
\text { salt flat } \\
\text { deposits }\end{array}$ & $\begin{array}{l}\text { Recent to late } \\
\text { Holocene }\end{array}$ & $\begin{array}{l}\text { White to } \\
\text { variegated light } \\
\text { and pastel colors; } \\
\text { light blue where } \\
\text { moist; smooth } \\
\text { textures }\end{array}$ & $\begin{array}{l}\text { White to light } \\
\text { grays }\end{array}$ & Basin interiors & None & None & None & None & $\begin{array}{l}\text { None; local near- } \\
\text { surface } \\
\text { encrustations on } \\
\text { salt pans }\end{array}$ & $\begin{array}{l}\text { Clay and silt; } \\
\text { local fine sand }\end{array}$ \\
\hline QTd & $\begin{array}{c}\text { Qsm, } \\
\text { Qcm,Qt }\end{array}$ & & $\begin{array}{l}\text { Inactive } \\
\text { and } \\
\text { active } \\
\text { discharge } \\
\text { deposits }\end{array}$ & $\begin{array}{l}\text { Recent to } \\
\text { Pliocene }\end{array}$ & $\begin{array}{l}\text { White to } \\
\text { variegated light } \\
\text { and pastel colors; } \\
\text { light blue where } \\
\text { moist; smooth to } \\
\text { medium textures; } \\
\text { local green } \\
\text { vegetation }\end{array}$ & $\begin{array}{l}\text { White to light } \\
\text { grays }\end{array}$ & $\begin{array}{c}\text { Mostly distal } \\
\text { piedmonts and } \\
\text { basin interiors; } \\
\text { locally proximal to } \\
\text { medial piedmonts }\end{array}$ & $\begin{array}{l}\text { None to } \\
\text { moderate }\end{array}$ & $\begin{array}{c}\text { None; } \\
\text { locally weak } \\
\text { to moderate } \\
\text { on alluvial } \\
\text { caps }\end{array}$ & $\begin{array}{l}\text { N/A; none to } \\
\text { weak on } \\
\text { alluvial } \\
\text { caps) }\end{array}$ & $\begin{array}{l}\text { None to weak } \\
\text { (on alluvial } \\
\text { caps) }\end{array}$ & $\begin{array}{l}\text { None to moderate } \\
\text { (may include St I- } \\
\text { II calcic horizons) }\end{array}$ & $\begin{array}{c}\text { Clay, silt, fine } \\
\text { sand; local } \\
\text { fine gravels } \\
\text { and organic } \\
\text { mats }\end{array}$ \\
\hline
\end{tabular}

1. Labels used to identify surficial units for three surficial mapping studies used in the digital mapping, as discussed in text. These include Workman and others (2002), Hunt and Mabey (1966) and 
Bull (1991). Units are subdivided into alluvial and other ( ie., lacustrine, playa/salt flat, eolian, ground-water discharge). Bull (1991) only includes alluvial units. Excluded from table are composite or mixed age-range alluvial units (Qau and QTau) and the bedrock landslide unit (QTls) for reasons explained in table header.

2. General type or classification of deposit, including general size range of coarse fraction, such that medium- to coarse-grained refers to gravel and sand and fine-grained refers to sand, silt and clay.

3. Age range of deposits, based on correlations to local or regional studies with geochronologic control listed in Menges and others (2001).

4.Typical characteristics of units observed in satellite image maps and aerial photography used in digital mapping and Workman and others (2002). This includes specially processed Landsat 7 Thematic Mapper images (composite bands 2,5,7) and panchromatic satellite images (Band 8, Landsat 7 TM and SPOT) and black/white high-altitude aerial photogrpahy.

5. Typical physiographic positions of unit within landscape, commonly given in reference to alluvial basins and (or) bedrock ranges.

6. Relative amount of local dissection or incision of drainages within or along margins of given mapped area of deposit. Common depth ranges include 0-2 $\mathrm{m}$ (minor), $2-5 \mathrm{~m}$ (moderate) and $>5 \mathrm{~m}$ (strong)

7. Characteristics of geomorphic surface associated with a given unit deposit. Subcategories listed are: qualitative strength of surface pavement development, including smoothness and degree of interlocking clasts, and the preservation of original depositional form, given in reference to bar and swale morphology (ie., original channel bars and distributary channels, respectively).

8. Degree of desert varnish observed at surface, given qualitatively in reference to darkening of tops and (or) reddening of undersides of surface clasts.

9. General strength of maximum soil development associated with upper surface of deposits, typically as observed in natural outcrops (gullies) or road cuts, or as exposed in shallow pits. Soil pits exposing the full depth range of deep profiles could not be excavated during the reconnaissance field traverses required for this project. Observations focused on relative degree of development of horizons of secondary accumulation of carbonate, after Machette (1985) and locally salt or silica, and presence or absence of cambic or argillic horizons. In some cases, generalized soil

characteristics were inferred less reliably where soil were not exposed on undissected surfaces from features on surface, including carbonate chips, carbonate rinds on clasts, and materials brought up from burrowing insects or rodents.

10. Typical textural size range of deposits, given for gravels in terms of coarse (cobble to boulder) or fine (pebble to cobble) grained. 
Table 2

Summary of spectral means for surficial basin units

\section{Regional Flow Model}

MEAN Unit

53 bedrock

67 Qtaf tecopa

$\begin{array}{lll}49 & \text { Qb } & \text { basalt } \\ 71 & \text { QTb } & \text { basalt }\end{array}$

63 Qta Q1, ballena

Qtau Q1,2,3 undifferentiated

Qfo Q2

Qau Q3 and Q2, but mainly Q3

Qfy Q3

Qay Q3, fine grained, Q4

Qfi Q3a and Q3b

Qac stream channel, Q4

QTd discharge?

QTpd marsh/discharge

QI lacustrine

Qe eolian

Qp playa

\section{HUNT AND MABEY}

MEAN Unit

52 bedrock

$\begin{array}{lll}76 & \text { Tf } & \text { furnace creek fm } \\ 55 & \text { Tg } & \text { granite } \\ 54 & \text { Tsr } & \text { sedimentary } \\ 57 & \text { Td } & \text { dikes } \\ 57 & \text { Tv } & \text { volcanic }\end{array}$

$56 \quad$ Qg2

$58 \quad$ Qg3

$66 \quad$ Qg4 similar to Qf

85

Qf fan flood plane

Qsm marsh, sulfate

lacustrine

Qd dune sand

Qsh salt, sulfate, surface layer

Qsc sandy playa, carbonate

Qch saline, surface carbonate

Qsci silty playa, carbonate

105

Qh salt, massive rock salt

Qhe salt, chlorite zone

\section{MENGES, field observations}

MEAN Unit

53 bedrock

56 Ts Ts

$\begin{array}{lll}61 & \text { Qta } & \text { Qt1 } \\ 64 & \text { Qao } & \text { Q2 } \\ 65 & \text { Qau } & \text { Q3/Q2 } \\ 67 & \text { Qay } & \text { Q3 } \\ 79 & \text { Qayf } & \text { Q3 (fg) } \\ & & \\ 74 & \text { Qc } & \text { channel } \\ & & \\ & & \\ 88 & \text { QTd } & \text { discharge (marsh) } \\ 54 & \text { Qlc } & \text { Qlc lake gravels Q2 } \\ 78 & \text { Qe } & \text { eolian }\end{array}$


Qhr silty rock salt rough

Qhs silty rock salt, smooth

Qsg salt, massive gypsum

48 Qt travertine

56 Qe mislabled 
Table 3

Slope values for surficial units from Hunt and Mabey (1966)

\begin{tabular}{|c|c|c|c|c|c|}
\hline $\begin{array}{c}\text { Hunt and } \\
\text { Mabey (1966) }\end{array}$ & median & mean & std & majority & Lithologic description \\
\hline & degrees & degrees & & degrees & \\
\hline Qsm & 0 & 2.18 & 7.2 & 0 & marsh \\
\hline Qcm & 0 & 0.42 & 0.5 & 0 & marsh 2 \\
\hline Qcs & 0 & 0.35 & 0.9 & 0 & sand facies \\
\hline Qcsi & 0 & 0.10 & 0.4 & 0 & silt, playa \\
\hline Qd & 0 & 0.27 & 0.5 & 0 & $\begin{array}{l}\text { dune sand, non } \\
\text { saline }\end{array}$ \\
\hline Qf & 0 & 1.15 & 3.0 & 0 & flood plains, non saline \\
\hline Qh & 0 & 0.01 & 0.1 & 0 & massive rock salt \\
\hline Qhe & 0 & 0.02 & 0.1 & 0 & $\begin{array}{l}\text { eroded } \\
\text { salt }\end{array}$ \\
\hline Qhr & 0 & 0.04 & 0.2 & 0 & silty rock salt \\
\hline Qhs & 0 & 0.04 & 0.3 & 0 & silty rock salt \\
\hline Qsg & 0 & 0.07 & 0.3 & 0 & massive gypsum \\
\hline Qsh & 0 & 0.05 & 0.2 & 0 & $\begin{array}{l}\text { saline facies of carbonate/sulfate } \\
\text { zones }\end{array}$ \\
\hline Qch & 0 & 0.14 & 0.5 & 0 & saline facies of carbonate zones \\
\hline Qg2 & 5 & 6.58 & 4.9 & 4 & $\begin{array}{l}\text { Q1 of Bull, may include some } \\
\text { QTs and Q2 }\end{array}$ \\
\hline Qg3 & 4 & 4.29 & 3.4 & 3 & $\begin{array}{l}\text { has desert pavement }=\text { Q2 \& } 3 \text { of } \\
\text { Bull }\end{array}$ \\
\hline Qg4 & 3 & 4.90 & 5.4 & 3 & $\begin{array}{l}\text { youngest alluvial fan, washes } \\
\text { and flood plain }\end{array}$ \\
\hline $\mathrm{TI}$ & 9 & 9.77 & 4.8 & 8 & older lake beds \\
\hline Tsr & 8 & 9.30 & 5.9 & 5 & sedimentary rocks \\
\hline Tf & 9 & 11.38 & 8.5 & 4 & Furnace Creek Formation \\
\hline Qt & 19 & 20.59 & 8.9 & 14 & travertine \\
\hline $\mathrm{Td}$ & 20 & 20.93 & 9.1 & 19 & dikes \\
\hline $\operatorname{Tg}$ & 20 & 21.87 & 14.5 & 7 & granitic intrusion \\
\hline Tv & 22 & 22.20 & 10.9 & 23 & volcanic \\
\hline bedrock & 26 & 25.08 & 9.9 & 28 & bedrock \\
\hline
\end{tabular}


Table 4

Landsat TM Band 8 spectral values found in Hunt and Mabey (1966) Quaternary units

\section{ALLUVIAL FAN UNITS}

$\begin{array}{cccccccc}\begin{array}{c}\text { Hunt and } \\ \text { Mabey (1966) } \\ \text { unit symbol }\end{array} & \text { minimum } & \text { maximum } & \text { range } & \text { mean } & \text { STD } & \text { majority } & \text { median } \\ \text { bedrock } & 15 & 141 & 126 & 56 & 14 & 54 & 55 \\ \text { Qd } & 41 & 117 & 76 & 71 & 10 & 69 & 70 \\ \text { Qf } & 24 & 185 & 161 & 101 & 30 & 87 & 89 \\ \text { Qg2 (Bull, 1991) } & 22 & 104 & 82 & 57 & 7 & 54 & 56 \\ \text { Qg3 (Bull, 1991) } & 20 & 107 & 87 & 58 & 5 & 57 & 57 \\ \text { Qg4 (Bull, 1991) } & 21 & 184 & 163 & 65 & 12 & 64 & 64 \\ \text { Td } & 24 & 107 & 83 & 59 & 13 & 54 & 58 \\ \text { Tv } & 15 & 136 & 121 & 61 & 16 & 62 & 60\end{array}$

PLAYA UNITS

$\begin{array}{cccccccc}\text { unit } & \text { minimum } & \text { maximum } & \text { range } & \text { mean } & \text { STD } & \text { majority } & \text { median } \\ \text { Qcm } & 45 & 113 & 68 & 66 & 11 & 65 & 65 \\ \text { Qh } & 52 & 170 & 118 & 105 & 39 & 66 & 93 \\ \text { Qf } & 20 & 183 & 163 & 91 & 28 & 69 & 83 \\ \text { Qsc } & 31 & 118 & 87 & 79 & 14 & 70 & 74 \\ \text { Qd } & 44 & 135 & 91 & 74 & 13 & 70 & 71 \\ \text { Qcsi } & 46 & 175 & 129 & 77 & 11 & 74 & 76 \\ \text { Qhr } & 42 & 180 & 138 & 75 & 14 & 74 & 73 \\ \text { Qch } & 43 & 144 & 101 & 80 & 14 & 80 & 80 \\ \text { Qhe } & 44 & 177 & 133 & 85 & 20 & 81 & 82 \\ \text { Qhs } & 48 & 173 & 125 & 89 & 13 & 89 & 88 \\ \text { Qsg } & 45 & 138 & 93 & 91 & 14 & 89 & 89 \\ \text { Qsm } & 43 & 143 & 100 & 82 & 14 & 89 & 83 \\ \text { Qsh } & 49 & 183 & 134 & 94 & 13 & 91 & 93\end{array}$


Table 5

Landsat TM Band 8 spectral values found in GPS ground truth points Quaternary units

$\begin{array}{cccccccc}\begin{array}{c}\text { GPS ground } \\ \text { truth points }\end{array} & \text { minimum } & \text { maximum } & \text { range } & \text { mean } & \text { STD } & \text { majority } & \text { median } \\ \text { bedrock } & 36 & 128 & 92 & 60.6923 & 17.0115 & 61 & 36 \\ \text { Q1 } & 52 & 52 & 0 & 52 & 0 & 52 & 52 \\ \text { QTs } & 52 & 73 & 21 & 60.8462 & 6.7007 & 54 & 52 \\ \text { Q1,2,3 u } & 77 & 77 & 0 & 77 & 0 & 77 & 77 \\ \text { basalt } & 65 & 136 & 71 & 91.0588 & 17.9164 & 101 & 65 \\ \text { Qch } & 45 & 96 & 51 & 64.0262 & 9.6154 & 60 & 45 \\ \text { Qsm } & 52 & 74 & 22 & 65.5 & 6.994 & 52 & 52 \\ \text { Qsc } & 42 & 113 & 71 & 67.2314 & 10.8097 & 65 & 42 \\ \text { Qsci } & 62 & 99 & 37 & 78.4545 & 8.5638 & 72 & 62 \\ \text { Qe } & 51 & 108 & 57 & 72.3104 & 13.9978 & 62 & 51 \\ \text { Qf } & 69 & 83 & 14 & 78.8 & 5.0754 & 69 & 69 \\ \text { Tg } & 51 & 51 & 0 & 51 & 0 & 51 & 51 \\ \text { Tsr } & 58 & 58 & 0 & 58 & 0 & 58 & 58 \\ \text { Qg2 } & 52 & 59 & 7 & 55.75 & 2.4875 & 56 & 52\end{array}$




\section{Table 6}

\section{Landsat TM Band 8 spectral values found in}

Workman and other (2002) Quaternary units

$\begin{array}{cccccccc}\text { UNIT } & \text { min } & \text { max } & \text { range } & \text { mean } & \text { std } & \text { majority } & \text { median } \\ \text { Q2/Q3 } & 36 & 144 & 108 & 62.1212 & 8.3978 & 60 & 61 \\ \text { Q2 } & 41 & 114 & 73 & 61.934 & 6.97 & 63 & 61 \\ \text { Q3, } & 39 & 170 & 131 & 67.5699 & 8.5885 & 64 & 67 \\ \text { basaltic-fan?? } & 40 & 119 & 79 & 72.0999 & 12.1056 & 67 & 71 \\ \text { Q 3,4 active wash } & 27 & 198 & 171 & 77.3419 & 14.6808 & 68 & 76 \\ \text { flood plain } & 34 & 179 & 145 & 78.6575 & 13.1066 & 70 & 76 \\ \text { salt flat } & 40 & 186 & 146 & 96.5454 & 30.1269 & 70 & 88 \\ \text { mislabled? } & 44 & 143 & 99 & 80.947 & 11.3958 & 84 & 81 \\ \text { flood plain/salt crust } & 24 & 209 & 185 & 96.9033 & 17.074 & 91 & 95\end{array}$




\section{Table 7 \\ TM 7 Classification Ranges \\ Of BAND 8 spectral data}

\begin{tabular}{|c|c|}
\hline \multicolumn{2}{|c|}{ Playa } \\
\hline Range & Lithology \\
\hline $0-49$ & active discharge \\
\hline $50-61$ & marsh \\
\hline $62-76$ & silty, sandy, active axial wash \\
\hline $77-99$ & salt flats, Qsm, discharge, silty-sandy-carbonate- mainly rims playa \\
\hline $100-119$ & saline marsh? \\
\hline $120-255$ & salt flat, playa \\
\hline \multicolumn{2}{|c|}{ Fan } \\
\hline Range & Lithology \\
\hline $0-41$ & bedrock \\
\hline $42-53$ & $Q_{2 / 3}$ Hunt and Mabey (1966), $Q_{2}$ Bull (1991) \\
\hline $54-59$ & $Q_{4}$ Hunt and Mabey (1966), $Q_{3}$ Bull (1991) \\
\hline $60-100$ & Qf Hunt and Mabey (1966), Q4 Bull (1991) \\
\hline $100-255$ & Q4, +/- paleodischarge \\
\hline
\end{tabular}




\section{Table 8}

Landsat TM Band 8 spectral values found in Quaternary units of the thematic surficial deposits map

\begin{tabular}{|c|c|c|c|c|c|c|c|c|c|}
\hline $\begin{array}{l}\text { database } \\
\text { code }\end{array}$ & cell count & inimum & maximum & range & mean & STD & majority & median & $\begin{array}{l}\text { Lithology } \\
\text { /unit }\end{array}$ \\
\hline 0 & 8,813 & 14 & 75 & 61 & 41.5 & 7.7 & 47 & 43 & bedrock \\
\hline 1 & 109,376 & 22 & 98 & 76 & 56.7 & 4.0 & 59 & 57 & marsh \\
\hline 2 & 723,867 & 21 & 165 & 144 & 69.1 & 5.1 & 69 & 69 & $\begin{array}{l}\text { Silty/sandy } \\
\text { playa }\end{array}$ \\
\hline 3 & 831,582 & 27 & 160 & 133 & 85.7 & 8.2 & 83 & 85 & flood plain \\
\hline 4 & 168,682 & 32 & 204 & 172 & 105.5 & 9.0 & 103 & 105 & salt flat 1 \\
\hline 5 & 106,999 & 28 & 209 & 181 & 135.7 & 15.8 & 126 & 135 & salt falt 2 \\
\hline 100 & 562 & 39 & 100 & 61 & 62.0 & 9.6 & 64 & 62 & nulldata \\
\hline 101 & 671,337 & 26 & 107 & 81 & 49.6 & 3.4 & 51 & 50 & Q2 \\
\hline 103 & $1,154,344$ & 26 & 108 & 82 & 56.1 & 2.8 & 56 & 56 & Q3 \\
\hline 104 & $2,065,606$ & 20 & 182 & 162 & 68.1 & 11.1 & 61 & 65 & Q4 \\
\hline 149 & $2,842,100$ & 10 & 197 & 187 & 49.6 & 15.7 & 42 & 49 & Q1+/- \\
\hline 198 & $1,449,198$ & 14 & 199 & 185 & 55.7 & 11.2 & 53 & 55 & bedrock \\
\hline
\end{tabular}




\section{Table 9}

Table showing qualitative evalution of thematic surfical deposits map

Assessment

Excellent

Very Good/Well

Satisfactory

Unsatisfactory

Poor
Agreement to exisitng

Map Area

$95 \%$ or better

$90-95 \%$

$85-90 \%$

$75-85 \%$

less than $75 \%$
Agreement to exisiting

Map boundary

$95 \%$ or better

$90-95 \%$

$85-90 \%$

$75-85 \%$

less than $75 \%$ 